\title{
A novel class of multitarget anti-Alzheimer benzohomoadamantane-chlorotacrine hybrids modulating cholinesterases and glutamate NMDA receptors
}

\section{F. Javier Pérez-Areales ${ }^{\mathrm{a}}$, Andreea L. Turcu ${ }^{\mathrm{a}}$, Marta Barniol-Xicota ${ }^{\mathrm{a}}$,}

Caterina Pont ${ }^{\mathrm{a}}$, Deborah Pivetta ${ }^{\mathrm{a}}$, Alba Espargarób ${ }^{\mathrm{b}}$, Manuela Bartolini ${ }^{\mathrm{c}}$, Angela De Simone ${ }^{\mathrm{d}}$, Vincenza Andrisano ${ }^{\mathrm{d}}$, Belén Pérez ${ }^{\mathrm{e}}$, Raimon Sabate ${ }^{\mathrm{b}}$, Francesc X. Sureda ${ }^{\mathrm{f}}$, Santiago Vázquez ${ }^{\mathrm{a},{ }^{*}}$, Diego Muñoz-Torrero ${ }^{\mathrm{a},{ }^{*}}$

${ }^{a}$ Laboratory of Pharmaceutical Chemistry (CSIC Associated Unit), Faculty of Pharmacy and Food Sciences, and Institute of Biomedicine (IBUB), University of Barcelona, Av. Joan XXIII 27-31, E-08028 Barcelona, Spain

${ }^{b}$ Department of Pharmacy and Pharmaceutical Technology and Physical-Chemistry, Faculty of Pharmacy and Food Sciences, and Institute of Nanoscience and Nanotechnology (IN2UB), University of Barcelona, Av. Joan XXIII 27-31, E-08028 Barcelona, Spain

${ }^{c}$ Department of Pharmacy and Biotechnology, Alma Mater Studiorum University of Bologna, Via Belmeloro 6, I-40126 Bologna, Italy

${ }^{d}$ Department for Life Quality Studies, Alma Mater Studiorum University of Bologna, Corso d'Augusto 237, I-47921 Rimini, Italy

${ }^{e}$ Department of Pharmacology, Therapeutics, and Toxicology, Autonomous University of Barcelona, E-08193 Bellaterra, Spain

${ }^{f}$ Pharmacology Unit, Faculty of Medicine and Health Sciences, Universitat Rovira $i$ Virgili, c/St. Llorenç 21, E-43201 Reus, Spain

* Corresponding authors. Tel.: +34 934024533; E-mail addresses: svazquez@ub.edu (S. Vázquez); dmunoztorrero@ub.edu (D.Muñoz-Torrero). 


\section{ABSTRACT}

The development of multitarget compounds against multifactorial diseases, such as Alzheimer's disease, is an area of very intensive research, due to the expected superior therapeutic efficacy that should arise from the simultaneous modulation of several key targets of the complex pathological network. Here we describe the synthesis and multitarget biological profiling of a new class of compounds designed by molecular hybridization of an NMDA receptor antagonist fluorobenzohomoadamantanamine with the potent acetylcholinesterase $(\mathrm{AChE})$ inhibitor 6-chlorotacrine, using two different linker lengths and linkage positions, to preserve or not the memantine-like polycyclic unsubstituted primary amine. The best hybrids exhibit greater potencies than parent compounds against $\mathrm{AChE}$ ( $\mathrm{IC}_{50} 0.33 \mathrm{nM}$ in the best case, 44 -fold increased potency over 6-chlorotacrine), butyrylcholinesterase ( $\mathrm{IC}_{50} 21 \mathrm{nM}$ in the best case, 24-fold increased potency over 6-chlorotacrine), and NMDA receptors ( $\mathrm{IC}_{50} 0.89 \mu \mathrm{M}$ in the best case, 2-fold increased potency over the parent benzohomoadamantanamine and memantine), which suggests an additive effect of both pharmacophoric moieties in the interaction with the primary targets. Moreover, most of these compounds have been predicted to be brain permeable. This set of biological properties makes them promising leads for further anti-Alzheimer drug development.

Keywords: Multitarget compounds

Multi-target-directed ligands

Acetylcholinesterase inhibitors

Butyrylcholinesterase inhibitors

NMDA antagonists

Brain permeability 


\section{Introduction}

Alzheimer's disease (AD) is a chronic neurodegenerative disorder that causes cognitive impairment and inexorably leads to dementia and death. With age being the main risk factor, the societal burden of $\mathrm{AD}$ in an increasingly aging population is reaching alarming proportions worldwide. The most worrisome predictions about AD prevalence, mortality, and associated economic costs are being continuously exceeded [1], thereby putting health systems and national economies at unmanageable risk if current drug discovery efforts do not result in efficacious treatments.

Only four drugs are currently used for AD treatment, namely the acetylcholinesterase (AChE) inhibitors donepezil, galantamine, and rivastigmine, and the glutamate NMDA receptor antagonist memantine. These drugs address the marked impairment in neurotransmitter systems, prominently the cholinergic and the glutamatergic system that occur in $\mathrm{AD}$ patients as a consequence of synaptic dysfunction and neuronal death, which is one of the main histopathological hallmarks of AD. Other two common features are senile plaques and neurofibrillary tangles, which result from overproduction and aggregation of $\beta$-amyloid peptide $(\mathrm{A} \beta)$ and hyperphosphorylation and aggregation of tau protein, respectively. Despite some evidence of disease-modifying effects by the currently approved anti-Alzheimer drugs [2-7], they are regarded and used as symptomatic drugs. Since the launching of these drugs, research efforts have pursued the development of alternative neurotransmitter-based symptomatic therapies and, mainly, new drugs that act specifically on a given biological target or event with a prominent pathogenic role, in most cases related to $A \beta$ and tau biology. Unfortunately, the enormous amounts of research efforts and resources that have been invested in the past three decades have not been corresponded by the discovery of novel drugs that have proven capable of halting or even just slowing down the neurodegenerative processes occurring in this fatal disease. Indeed, AD is one of the therapeutic areas with the highest attrition rates in clinical trials [8,9]. Very disappointingly, no drug candidate has successfully passed phase III clinical trials for AD since the launching of memantine, almost two decades ago.

The repetitive failures of very promising target-specific drugs in clinical trials is leading to a growing awareness of the complex multifactorial nature of $\mathrm{AD}$, which could result from the dysregulation of multiple separate but integrated signaling pathways. A scenario of a complex pathogenic network would account for the lack of efficacy of drugs that address a particular signaling pathway by modulation of a single biological 
target, and warrants the development of alternative therapeutic approaches based on the simultaneous modulation of several crucial biological targets, which should result in additive or synergistic effects [10,11]. Multitarget treatments may involve the use of several specific drugs (drug cocktails or fixed-dose combinations) or a single drug with the ability to hit several biological targets (multitarget drugs). Even though the design and development of multitarget drugs can be very challenging [12], it has some clear advantages over multiple-medication therapies, such as simpler dose regimens and improved patient compliance, simpler pharmacokinetics and lack of drug-drug interactions, and simpler clinical development, among others $[13,14]$. In fact, both strategies are being currently used in AD treatment or pursued in AD drug discovery. On the one hand, the combination of the AChE inhibitor donepezil with the glutamate NMDA antagonist memantine has proven to lead to additive or synergistic effects in mouse models and AD patients [15-17], and a fixed-dose combination of both drugs (Namzaric ${ }^{\circledR}$ ) is now being used as the standard of care to treat dementia associated with moderate to severe stages of the disease $[18,19]$. On the other hand, AD is one of the therapeutic areas where the development of multitarget drugs has been more intensively pursued in the past decade [20-22]. Most of these compounds are hybrids that combine distinct pharmacophoric moieties to confer multiple activities [for recent examples see 23-37]. A crucial point in the design of multitarget anti-Alzheimer compounds is the selection of the biological targets to hit, and, hence, of the pharmacophores to be used. Many different combinations of targets have been considered, with most of them including AChE. Particularly, the mechanism of action of the currently marketed antiAlzheimer drugs and the fact that the combination of both mechanisms in the fixed-dose combination of an AChE inhibitor (donepezil) and a glutamate NMDA receptor antagonist (memantine) results in improved clinical efficacy have provided a valuable clue for the design of hybrid compounds that combine pharmacophoric moieties to impart those activities [38-40]. Some of these compounds feature a moiety of a wellknown AChE inhibitor, such as galantamine or 7-methoxytacrine [41], linked through an oligomethylene tether to a memantine or the closely related amantadine unit (compounds 3-5, Figure 1) [42-45]. These compounds exhibit nanomolar to submicromolar AChE inhibitory activities and low micromolar affinities towards glutamate NMDA receptors, slightly lower than that of memantine. Very interestingly, one of them, ARN14140, gave cognition enhancing effects and balanced the levels of biomarkers of neurodegeneration, synaptic plasticity, and apoptosis in a non-transgenic 
mouse model of $\mathrm{AD}$ [43], thereby highlighting the therapeutic potential of the combination of AChE inhibition and NMDA receptor antagonism in a single multitarget molecule.

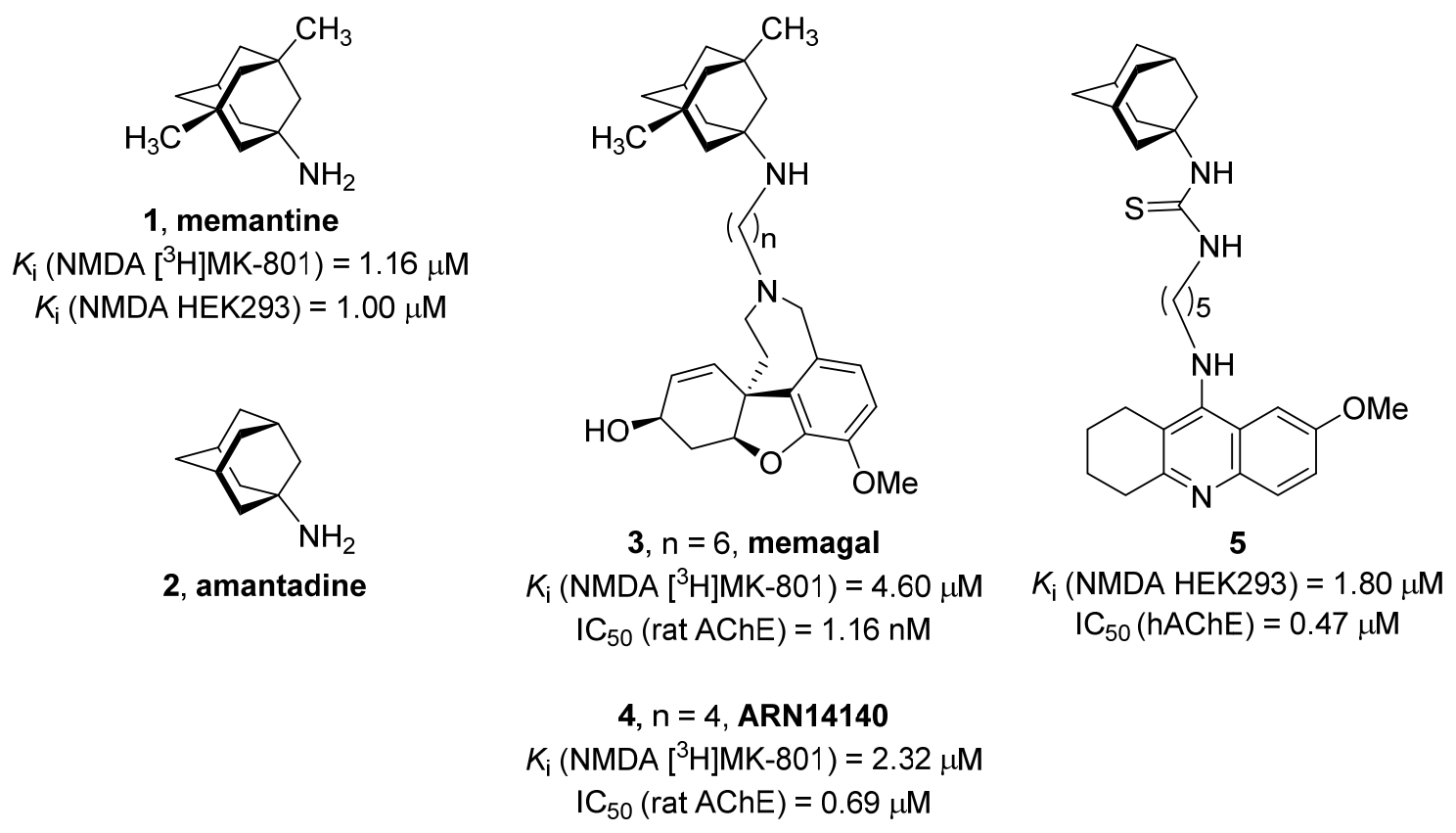

Fig. 1. Structures of memantine, amantadine, and derivatives 3-5 with dual glutamate NMDA receptor affinity and AChE inhibitory activity.

During the past decade we have been exploring the glutamate NMDA receptor antagonistic activity of novel polycyclic amines featuring oxaadamantane [46], noradamantane and bisnoradamantane [47], benzohomooxaadamantane [48], and benzohomoadamantane $[49,50]$ scaffolds, as bioisosteric, ring-contracted or ringexpanded analogs of memantine. Among these compounds, the fluorobenzohomoadamantanamine 6 (Figure 2) and its non-fluorinated analog turned out to be the most potent NMDA receptor antagonists, with potencies very close to that of memantine in a functional assay in rat cultured cerebellar granule neurons (CGN) [50]. 


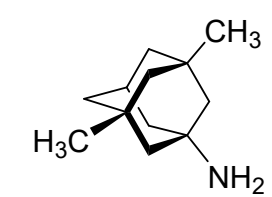

1, memantine $\mathrm{IC}_{50}(\mathrm{NMDA}$ CGN $)=1.50 \mu \mathrm{M}$

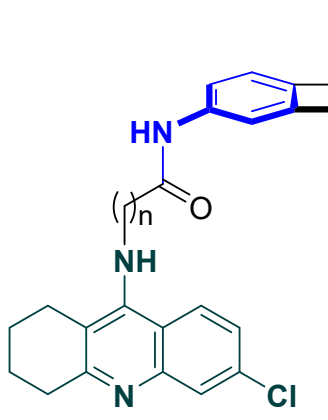

$\mathrm{n}=3,4$

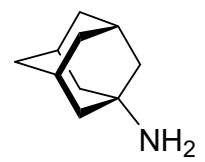

2, amantadine

$\mathrm{IC}_{50}(\mathrm{NMDA}$ CGN $)=92 \mu \mathrm{M}$

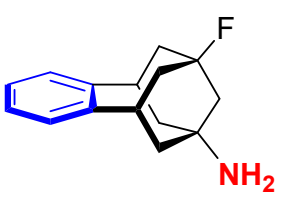

6 alternative linkage to leave unsubstituted the primary amino group

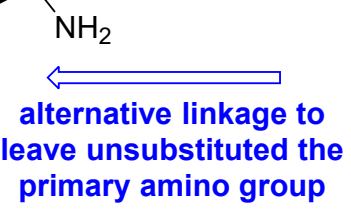

6

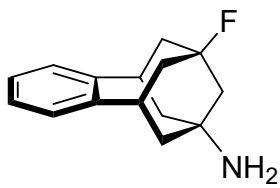

6

$\mathrm{IC}_{50}(\mathrm{NMDA}$ CGN $)=1.93 \mu \mathrm{M}$ amino group

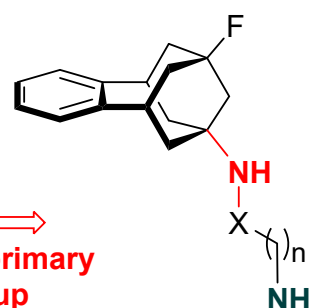

6-chlorotacrine moiety

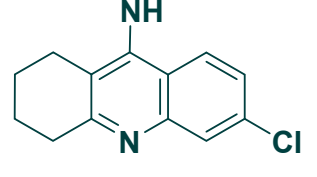

$\mathrm{X}=\mathrm{C}=\mathrm{O}$ or $\mathrm{CH}_{2}$ $\mathrm{n}=3,4$

Fig. 2. Structure of the benzohomoadamantanamine $\mathbf{6}$ and design of the novel hybrids derived from 6 and the AChE inhibitor 6-chlorotacrine.

The proven therapeutic potential of the combination of glutamate NMDA receptor antagonism with AChE inhibition, the interesting NMDA antagonistic activity of the benzohomoadamantanamine $\mathbf{6}$, and our own experience in the development of multitarget anti-Alzheimer compounds containing AChE inhibitor pharmacophores [5154] prompted us to undertake the design of a novel class of multitarget hybrid compounds featuring the aminopolycyclic scaffold of $\mathbf{6}$ and a unit of the potent $\mathrm{AChE}$ inhibitor 6-chlorotacrine [55] (Figure 2). In all memantine- or amantadine-based multitarget hybrids previously reported, the aminopolycyclic moiety is linked to the $\mathrm{AChE}$ inhibitor moiety through the amino group. It has been reported that alkylation (monomethylation) of the amino group of memantine leads to a twofold decrease of affinity and antagonistic activity towards NMDA receptors, whereas dialkylation has a much more dramatic effect (3-fold reduced affinity and 12-fold reduced NMDA antagonistic activity) [56]. This trend was also observed in some of the polycyclic amines we had developed as NMDA receptor antagonists $[47,49,50]$, but not in all of them $[46,48]$. To further shed light on this, we envisaged the synthesis of two short series of benzohomoadamantane-chlorotacrine hybrids, where the attachment point of the aminopolycyclic moiety to the rest of the molecule was either the bridgehead aliphatic primary amino group or a second amino group placed at the benzene ring, 
thereby leaving unsubstituted the "memantine-like" aliphatic amino group (Figure 2). A linker length similar to that used in the previously reported memantine- or amantadinebased multitarget compounds was envisaged for the novel benzohomoadamantanechlorotacrine hybrids.

Here we report the synthesis of this novel class of benzohomoadamantane-chlorotacrine hybrids and their in vitro biological profiling, including the determination of their inhibitory activity against both human cholinesterases (human AChE (hAChE) and human butyrylcholinesterase (hBChE)), glutamate NMDA receptor antagonistic activity, and brain permeability. Because other families of 6-chlorotacrine-related hybrids developed in our group have shown activity against the enzyme BACE-1 ( $\beta$ secretase) and A $\beta 42$ and tau aggregation [51-54], the novel benzohomoadamantanechlorotacrine hybrids were also evaluated against these other targets of interest in AD treatment.

\section{Results and discussion}

\subsection{Synthesis of the novel benzohomoadamantane-chlorotacrine hybrids}

The synthesis of the target hybrids $\mathbf{1 3} \mathbf{a}$ and $\mathbf{1 3} \mathbf{b}$, in which the benzohomoadamantanamine moiety was linked throught its primary amino group to the chlorotacrine unit, was carried out by the alternative sequences depicted in Scheme 1, using 6-chlorotacrine, 7 [55], or the dichloroacridine derivative 8 [57] as the starting materials. We initially envisaged a four-step route that involved alkylation of 6chlorotacrine with the appropriate $\omega$-bromoalkanenitrile, followed by hydrolysis of the cyano group, amide coupling of the resulting carboxylic acid with the benzohomoadamantanamine $\mathbf{6}$, and final reduction of the amide to the secondary amine. Reaction of 6-chlorotacrine, 7, with 5-bromovaleronitrile, in the presence of $\mathrm{KOH}$ in dry DMSO led in moderate yield (64\%) to the new nitrile 11b, after silica gel column chromatography purification. However, different attempts to alkylate 7 with $4-$ bromobutyronitrile failed to afford the shorter homologue 11a. The new nitrile 11a was alternatively obtained, in $92 \%$ overall yield, by amination of the dichloroacridine derivative 8 with 3-amino-1-propanol at $135^{\circ} \mathrm{C}$, followed by mesylation of the resulting alcohol 9a [58], and reaction of mesylate 10a [58] with $\mathrm{NaCN}$ in dry DMF (Scheme 1). Alkaline hydrolysis of nitriles 11a and 11b, followed by acidification with an $\mathrm{Et}_{2} \mathrm{O}$ solution of $\mathrm{HCl}$ afforded the corresponding carboxylic acids, in the form of quinoline hydrochloride salts, which were directly coupled with amine $\mathbf{6}$ using EDC and HOBt, to 
yield amides 12a and 12b in moderate yields (40\% and 75\% overall), after silica gel column chromatography purification. Reduction of amides $\mathbf{1 2 a}$ and $\mathbf{1 2 b}$ to the corresponding secondary amines turned out to be a difficult task. Different attempts of reduction with $\mathrm{LiAlH}_{4}, \mathrm{LiBH}_{4}$, or sodium bis(2-methoxyethoxy)aluminium hydride (Red-Al $\left.{ }^{\circledR}\right)$ were fruitless. Finally, borane reduction of amides $\mathbf{1 2} \mathbf{a}$ and $\mathbf{1 2 b}$ did afford the target amines 13a and 13b, albeit in low yield (24\% and $10 \%$, respectively).

Alternatively, amine 13b was obtained by alkylation of amine 6 with mesylate $\mathbf{1 0 b}$, which was prepared by amination of chloroquinoline 8 with 5-amino-1-pentanol at 135 ${ }^{\circ} \mathrm{C}$, followed by mesylation of the resulting alcohol $\mathbf{9 b}$. Under these conditions, $\mathbf{1 3 b}$ was obtained in higher yield (27\%) but it was accompanied with some byproducts arising from degradation of the mesylate.<smiles>Nc1c2c(nc3cc(Cl)ccc13)CCCC2</smiles>

7

(i) for $n=4$<smiles>Cc1ccc2c(NC(C#N)C#N)c3c(nc2c1)CCCC3</smiles>

$11 a, n=3$

11b, $n=4$

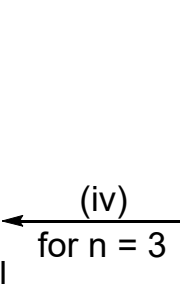<smiles>COc1ccccc1Nc1c2c(nc3cc(Cl)ccc13)CCCC2</smiles>

$10 a, n=3$

10b, $\mathrm{n}=5$<smiles>Clc1ccc2c(Cl)c3c(nc2c1)CCCC3</smiles>

(ii)<smiles>Oc1ccccc1Nc1c2c(nc3cc(Cl)ccc13)CCCC2</smiles>

9a, $n=3$

$9 b, n=5$<smiles>Clc1ccc2cc3c(nc2c1)CCCC3</smiles>

(v)
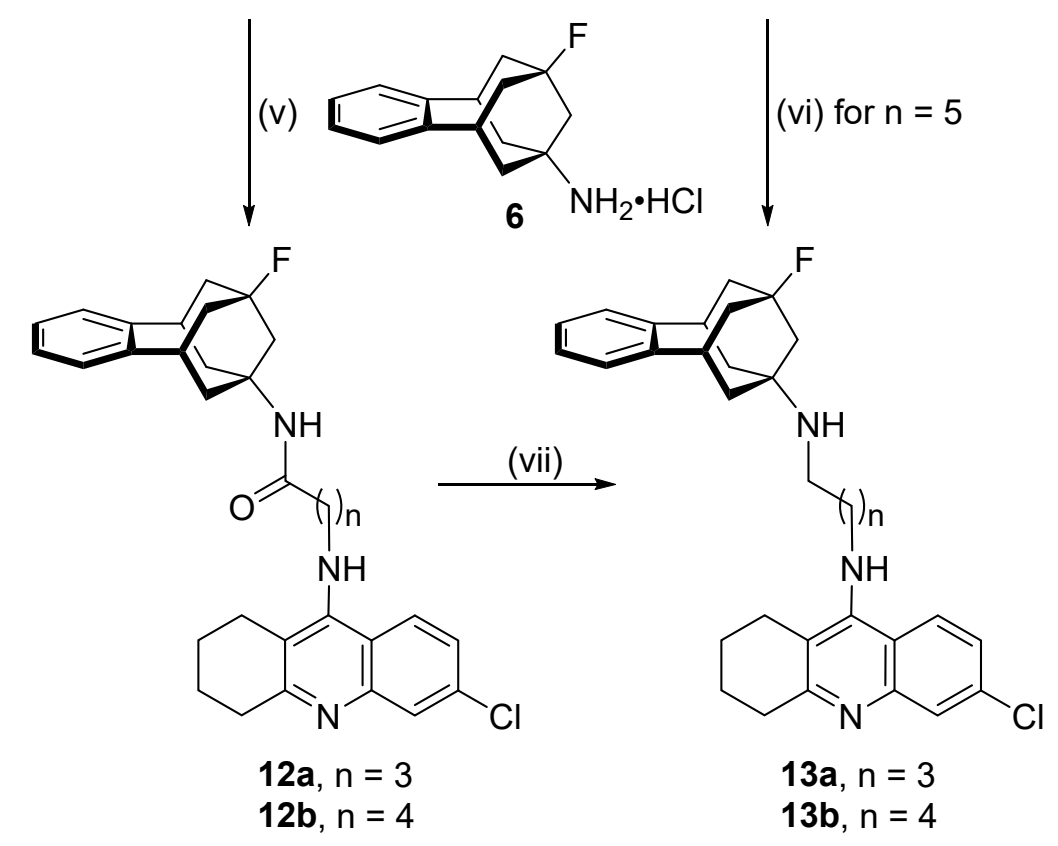

(iii) 
Scheme 1. Reagents and conditions: (i) 7, KOH, DMSO, rt, 2 h; then, 5bromovaleronitrile, rt, overnight, 11b (64\%); (ii) 3-amino-1-propanol or 5-amino-1pentanol, $135^{\circ} \mathrm{C}, 1$ day, 9a (94\%), 9b (40\%); (iii) $\mathrm{MsCl}, \mathrm{Et}_{3} \mathrm{~N}, \mathrm{CH}_{2} \mathrm{Cl}_{2},-10{ }^{\circ} \mathrm{C}, 30 \mathrm{~min}$, 10a (quantitative), $\mathbf{1 0 b}$ (quantitative); (iv) $\mathrm{NaCN}, \mathrm{DMF}, 100{ }^{\circ} \mathrm{C}, 1 \mathrm{~h}, \mathbf{1 1 a}(98 \%$ ); (v) 1) $40 \%$ methanolic $\mathrm{KOH}, \mathrm{MeOH}$, reflux, $3 \mathrm{~h}$; then, water, reflux, overnight; $\mathrm{HCl} / \mathrm{Et}_{2} \mathrm{O} ; 2$ ) crude carboxylic acid (quinoline hydrochloride salt), EDC· HCl, $\mathrm{HOBt}, \mathrm{Et}_{3} \mathrm{~N}, \mathrm{EtOAc} /$ DMF, rt, 15 min; then, 6, EtOAc / DMF, rt, 2 days, 12a (40\% overall yield from 11a), 12b (75\% overall yield from 11b); (vi) 6, $\mathrm{K}_{2} \mathrm{CO}_{3}, \mathrm{DMF}, 80{ }^{\circ} \mathrm{C}, 2$ days, $\mathbf{1 3 b}$ (27\%); (vii) $\mathrm{BH}_{3} \cdot \mathrm{THF}$, THF, $0{ }^{\circ} \mathrm{C}$; then, rt, overnight, 13a (24\%), 13b (10\%).

The synthesis of the second set of benzohomoadamantane-chlorotacrine hybrids, 18a and $\mathbf{1 8 b}$, where the chlorotacrine unit and tether chain were attached to the benzene ring of the aminopolycyclic moiety, was carried out using benzohomoadamantanamine 14, previously prepared in our group [59], and nitriles 11a and 11b as the key building blocks (Scheme 2). Amine 14 was $N$-Boc-protected and then subjected to hydrogenation at atmospheric pressure and room temperature, in the presence of $\mathrm{PtO}_{2}$ as catalyst, to afford the aniline $\mathbf{1 6}$ in good yield. Amide coupling of $\mathbf{1 6}$ with the carboxylic acids derived from hydrolysis of nitriles 11a and 11b led to the $N$-Boc-protected hybrids 17a and $\mathbf{1 7} \mathbf{b}$, which, upon treatment with $4 \mathrm{~N} \mathrm{HCl} /$ dioxane, were converted into the target hybrids 18a and 18b in moderate yield (49\% and 37\% overall yield from 11a and 11b, respectively). 

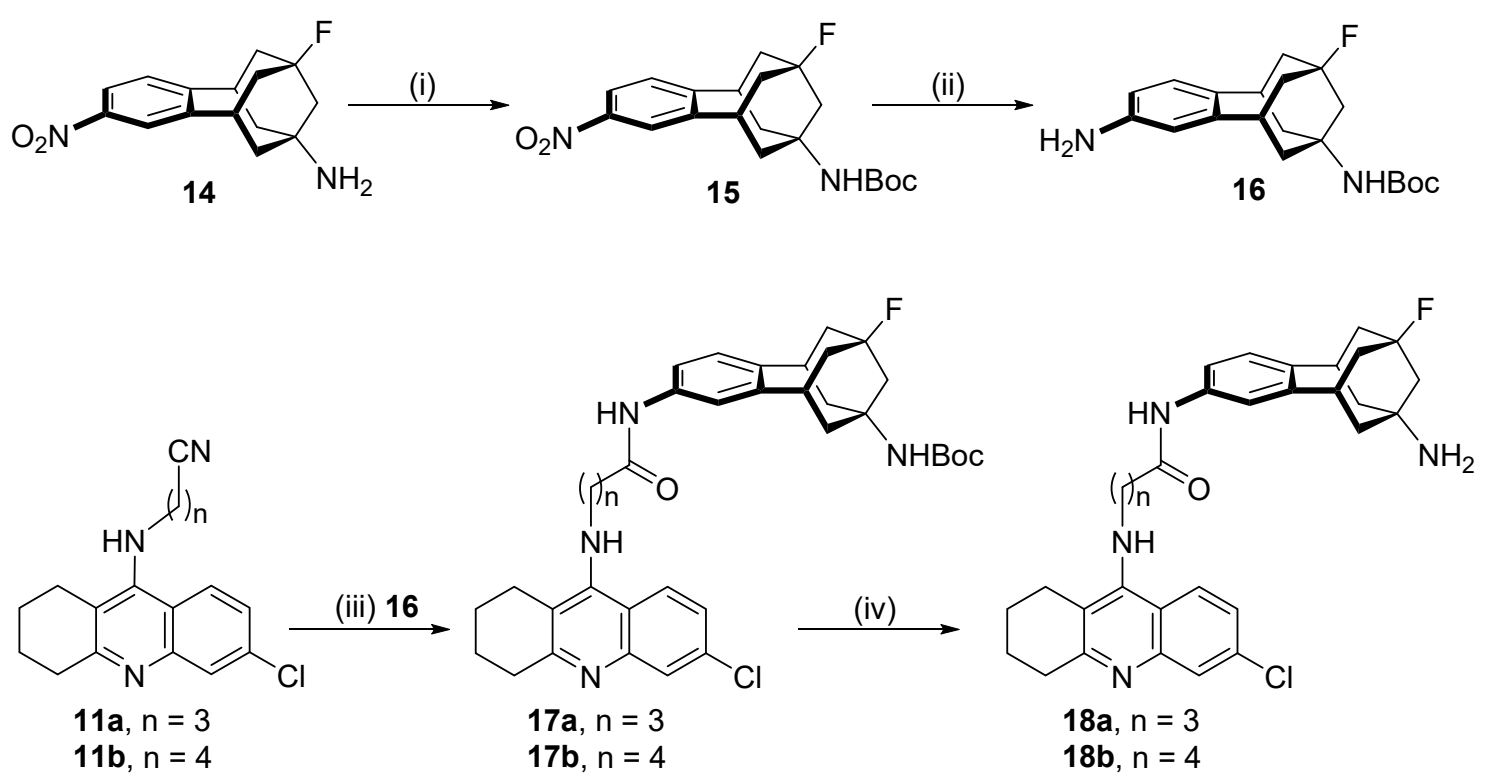

Scheme 2. Reagents and conditions: (i) $2 \mathrm{~N} \mathrm{NaOH}$, di-tert-butyl dicarbonate, rt, $16 \mathrm{~h}$, $87 \%$; (ii) $\mathrm{H}_{2}, \mathrm{PtO}_{2}, \mathrm{EtOH}, 1$ atm, rt, 4 h, 92\%; (iii) 1) 40\% methanolic $\mathrm{KOH}, \mathrm{MeOH}$, reflux, $3 \mathrm{~h}$; then, water, reflux, overnight; $\mathrm{HCl} / \mathrm{Et}_{2} \mathrm{O} ; 2$ ) crude carboxylic acid (quinoline hydrochloride salt), EDC $\cdot \mathrm{HCl}, \mathrm{HOBt}, \mathrm{Et} 3 \mathrm{~N}, \mathrm{EtOAc} / \mathrm{DMF}, \mathrm{rt}, 15 \mathrm{~min}$; then, 16, EtOAc / DMF, rt, 1 day; (iv) 4N HCl / dioxane, rt, 18 h, 18a (49\% overall yield from 11a), 18b (37\% overall yield from $11 \mathbf{b})$.

All the benzohomoadamantane-chlorotacrine hybrids were converted into the corresponding hydrochloride or dihydrochloride salts by treatment with $\mathrm{HCl} / \mathrm{MeOH}$, prior to their chemical characterization and biological profiling.

\subsection{Acetylcholinesterase and butyrylcholinesterase inhibition by the novel benzohomoadamantane-chlorotacrine hybrids}

Apart from AChE, the enzyme BChE is in part responsible for the hydrolysis of the neurotransmitter acetylcholine (ACh) in the central nervous system (CNS), thereby contributing to the cholinergic deficit characteristic of AD patients. This is especially true in advanced stages of the disease, in which the levels of AChE are markedly decreased, whereas the levels of $\mathrm{BChE}$ remain the same or even increase, thereby acquiring a prominent role in ACh breakdown [60]. Thus, BChE inhibition or even more interestingly, dual $\mathrm{AChE}$ and $\mathrm{BChE}$ inhibition are commonly pursued in the search for novel anti-Alzheimer drug candidates. In this light, the effect of the novel benzohomoadamantane-chlorotacrine hybrids $\mathbf{1 2 a}, \mathbf{b}, \mathbf{1 3 a}, \mathbf{b}$, and $\mathbf{1 8 a}, \mathbf{b}$ on human recombinant $\mathrm{AChE}(\mathrm{hAChE})$ and human serum $\mathrm{BChE}(\mathrm{hBChE})$ was determined by the 
method of Ellman et al. [61]. 6-Chlorotacrine, 7, was also evaluated under the same assay conditions as a reference compound for cholinesterases inhibition (Table 1).

\section{Table 1}

Inhibitory activities against $\mathrm{AChE}$ and $\mathrm{BChE}, \mathrm{NMDA}$ antagonistic activity, $\mathrm{A} \beta 42$ and tau anti-aggregating activity, and blood-brain barrier (BBB) predicted permeabilities of the benzohomoadamantane-chlorotacrine hybrids and reference compounds.

\begin{tabular}{|c|c|c|c|c|c|c|}
\hline Compd & $\begin{array}{l}\text { hAChE } \\
\mathrm{IC}_{50}(\mathrm{nM})^{\mathrm{a}}\end{array}$ & $\begin{array}{l}\mathrm{hBChE} \\
\mathrm{IC}_{50}(\mu \mathrm{M})^{\mathrm{a}}\end{array}$ & $\begin{array}{l}\text { NMDA } \\
\text { IC }_{50}(\mu \mathrm{M})^{\mathrm{b}}\end{array}$ & $\begin{array}{l}\mathrm{A} \beta 42 \\
\text { aggregation } \\
\text { in } E . \text { coli } \\
(\% \text { inhib. } \\
\text { at } 10 \mu \mathrm{M})^{\mathrm{c}}\end{array}$ & $\begin{array}{l}\text { Tau protein } \\
\text { aggregation } \\
\text { in } E . \text { coli } \\
(\% \text { inhib. } \\
\text { at } 10 \mu \mathrm{M})^{\mathrm{c}}\end{array}$ & $\begin{array}{l}P e\left(10^{-6} \mathrm{~cm} \mathrm{~s}^{-1}\right)^{\mathrm{d}} \\
\text { (Prediction) }\end{array}$ \\
\hline $12 a$ & $1.4 \pm 0.1$ & $2.3 \pm 0.1$ & $7.0 \pm 2.8$ & $<5$ & $10.2 \pm 2.4$ & $9.8 \pm 0.9(\mathrm{CNS}+)$ \\
\hline $12 b$ & $1.3 \pm 0.1$ & $2.4 \pm 0.2$ & $8.3 \pm 3.3$ & $9.0 \pm 1.2$ & $12.6 \pm 2.7$ & $9.0 \pm 0.5(\mathrm{CNS}+)$ \\
\hline $13 \mathbf{a}$ & $2.0 \pm 0.1$ & $1.1 \pm 0.1$ & $3.3 \pm 0.6$ & $8.4 \pm 2.2$ & $22.0 \pm 2.7$ & $6.3 \pm 0.1(\mathrm{CNS}+)$ \\
\hline $13 b$ & $1.4 \pm 0.1$ & $0.2 \pm 0.0$ & $0.9 \pm 0.1$ & $12.3 \pm 2.6$ & $20.7 \pm 2.4$ & $6.5 \pm 0.3(\mathrm{CNS}+)$ \\
\hline $18 \mathbf{a}$ & $0.3 \pm 0.0$ & $0.5 \pm 0.0$ & $1.2 \pm 0.2$ & $<5$ & $6.9 \pm 3.9$ & $2.7 \pm 0.6(\mathrm{CNS} \pm)$ \\
\hline $18 b$ & $2.5 \pm 0.5$ & $0.02 \pm 0.00$ & $3.4 \pm 1.2$ & $<5$ & $22.9 \pm 5.0$ & $3.1 \pm 0.7(\mathrm{CNS} \pm)$ \\
\hline 1 & $\mathrm{nd}^{\mathrm{e}}$ & $\mathrm{nd}^{\mathrm{e}}$ & $1.5 \pm 0.1$ & $n d^{e}$ & $\mathrm{nd}^{\mathrm{e}}$ & $n d^{\mathrm{e}}$ \\
\hline 6 & $\mathrm{nd}^{\mathrm{e}}$ & $\mathrm{nd}^{\mathrm{e}}$ & $1.9 \pm 0.2$ & $\mathrm{nd}^{\mathrm{e}}$ & $\mathrm{nd}^{\mathrm{e}}$ & $\mathrm{nd}^{\mathrm{e}}$ \\
\hline 7 & $14.5 \pm 0.9$ & $0.5 \pm 0.0$ & $\mathrm{nd}^{\mathrm{e}}$ & $<5$ & $<5$ & $20 \pm 0.4(\mathrm{CNS}+)$ \\
\hline
\end{tabular}

${ }^{\mathrm{a}} \mathrm{IC}_{50}$ inhibitory concentration (nM) towards human recombinant $\mathrm{AChE}$ and human serum $\mathrm{BChE}$. $\mathrm{IC}_{50}$ values are expressed as mean \pm standard error of the mean (SEM) of at least two experiments, each performed in triplicate.

${ }^{\mathrm{b}}$ Functional data were obtained from primary cultures of rat CGN challenged with NMDA (100 $\mu \mathrm{M}$, in the presence of $10 \mu \mathrm{M}$ glycine), by measuring the intracellular calcium concentration. Data shown are expressed as mean $\pm \mathrm{SEM}$ of at least three separate experiments carried out on three different batches of cultured cells. c $\%$ Inhibition of $\mathrm{A} \beta 42$ and tau protein aggregation at $10 \mu \mathrm{M}$ in intact $E$. coli cells. Values are expressed as mean \pm SEM of four independent experiments $(n=4)$.

${ }^{\mathrm{d}}$ Permeability values from the PAMPA-BBB assay. Values are expressed as the mean \pm SD of three independent experiments $(n=3)$.

${ }^{\mathrm{e}}$ Not determined. 
All the novel hybrids turned out to be highly potent hAChE inhibitors, with $\mathrm{IC}_{50}$ values from subnanomolar (18a: $0.33 \mathrm{nM})$ to $2.5 \mathrm{nM}$ (Table 1). Thus, the benzohomoadamantane-chlorotacrine hybrids are clearly more potent hAChE inhibitors (6-44-fold more potent) than the parent 6-chlorotacrine, 7, which is indicative of an additive or synergistic effect by the benzohomoadamantane moiety and/or the linker. In the first series, with $\mathrm{IC}_{50}$ values in the very narrow range of $1.30-1.96 \mathrm{nM}$, neither the linker length nor the presence of an amide or an amine as the attachment functionality to the benzohomoadamantane core seems to play a differential role in hAChE inhibition. Thus, amines 13a,b and amides 12a,b, longer and shorter homologues 12a-13a and 12b-13b exhibited the same hAChE inhibitory potency. In contrast, in the second series, the shorter homologue $\mathbf{1 8 a}$ was 8 -fold more potent than the longer homologue $\mathbf{1 8 b}$. Indeed, 18a is the most potent hAChE inhibitor among all the novel benzohomoadamantane-chlorotacrine hybrids, so that the presence of an unsubstituted primary amino group at the benzohomoadamantane core and/or the presence of an amido linkage at the benzene ring with that particular linker length seem the most favorable substitution pattern for hAChE inhibition.

In contrast to $\mathrm{hAChE}$ inhibition, a broader range of $\mathrm{IC}_{50}$ values for $\mathrm{hBChE}$ inhibition was found for the novel hybrids, i.e. from $21 \mathrm{nM}(\mathbf{1 8 b})$ to $2.36 \mu \mathrm{M}(\mathbf{1 2 b})$, as well as more defined structure-activity relationships. The presence of basic amino group at the benzohomoadamantane core seems to be important for hBChE inhibition, with secondary amines 13 being 2-11-fold more potent than their amido counterparts 12, and with the primary amines 18, with a different disposition of the linker, being still more potent (2-10-fold more potent than amines 13 and 5-100-fold more potent than amides 12). Within the amines $\mathbf{1 3}$ and $\mathbf{1 8}$, a longer tether chain leads to a 5-23-fold greater $\mathrm{hBChE}$ inhibitory activity. Thus, the most potent $\mathrm{hBChE}$ inhibitors were hybrids $\mathbf{1 3 b}$ and $\mathbf{1 8 b}$, which, with IC50 values of 210 and $21 \mathrm{nM}$, respectively, are 2- and 24-fold more potent than the parent 6-chlorotacrine. This supports the idea that the presence of the benzohomoadamantanamine moiety in these hybrids contributes positively to the interaction with the enzyme $\mathrm{BChE}$.

\subsection{NMDA receptor antagonistic activity of the novel benzohomoadamantane- chlorotacrine hybrids}

Apart from hAChE and hBChE, the NMDA receptor was the other primary biological target, which was pursued with the design of the benzohomoadamantane-chlorotacrine 
hybrids. In particular, we inferred that the incorporation of the aminopolycyclic scaffold of the fluorobenzohomoadamantanamine 6, an NMDA receptor antagonist developed in our group [50] that is equipotent to memantine, into the structure of the hybrids should confer this additional activity.

To assess the NMDA antagonistic activity of the novel hybrids, we performed a functional assay based on measuring their effects on the increase in intracellular calcium evoked by NMDA (100 $\mu \mathrm{M}$, in the presence of $10 \mu \mathrm{M}$ glycine) in cultured rat CGN loaded with Fura-2 [49]. Memantine, 1, and fluorobenzohomoadamantanamine 6 were used as reference compounds for NMDA antagonism (Table 1).

As previously mentioned, in all the described memantine- or amantadine-AChE inhibitor hybrids, the aminopolycyclic moiety is linked to the AChE inhibitor pharmacophore through its amino group. It has been described that alkylation of the amino group of memantine is detrimental for NMDA affinity and antagonistic activity, with monomethylation leading to a twofold reduced affinity and antagonistic activity, and dialkylation producing a 3-fold and 12-fold reduction of NMDA affinity and antagonistic activity, respectively [56]. A similar trend was also observed in some polycyclic amines that were developed in our group as NMDA receptor antagonists $[47,49,50]$, whereas the opposite trend was found in others $[46,48]$. In line with our previous reports, alkylation of the bridgehead amino group of the benzohomoadamantane core in the novel hybrids may lead to reduced (13a vs $\mathbf{6}$, twofold reduction) or increased (13b $v s \mathbf{6}$, twofold increase) NMDA antagonistic activity, with the linker length seeming to play a role (the longer homologue $\mathbf{1 3 b}$ is 4 fold more potent than the shorter counterpart 13a). Indeed, the most potent NMDA antagonist among the hybrids that are substituted at the bridgehead amino group, $\mathbf{1 3 b}$, is equipotent to the most potent hybrid featuring an unsubstituted bridgehead primary amino group, 18a. Thus, it seems that this class of compounds can tolerate monoalkylation of the polycyclic amino group without losing NMDA antagonistic activity. However, acylation of this amino group seems to be clearly detrimental for NMDA antagonistic activity, with amides $12 \mathbf{a}$ and $\mathbf{1 2 b}$ being 2- and 9-fold less potent than amines 13a and 13b. These results are in agreement with those found in memantine-galantamine hybrids, where amido-linked hybrids displayed NMDA affinities 2-4-fold lower than those of the corresponding amines [42]. Therefore, the presence of a basic nitrogen atom at a bridgehead position of the polycyclic core seems to be favourable for NMDA antagonistic activity. 
Overall, hybrids $\mathbf{1 3 b}$ and $\mathbf{1 8 a}$ are roughly twofold more potent NMDA antagonists than the parent benzohomoadamantanamine 6, which may be indicative of an additive effect of the chlorotacrine moiety in the interaction of the hybrids with these receptors. Moreover, these novel hybrids are equipotent or slightly more potent (1.7-fold) than the NMDA antagonistic anti-Alzheimer drug memantine.

\subsection{Evaluation of potential anti-amyloid activities of the novel benzohomoadamantane-} chlorotacrine hybrids

It has been shown that memantine inhibits in vitro the aggregation of human recombinant $\mathrm{A} \beta 42$ in a concentration-dependent manner, through NMDA receptorindependent mechanisms [62]. Also, chronic treatment with memantine leads to reduced brain levels of insoluble $A \beta$ and soluble $A \beta$ oligomers in several animal models of $A D$. On the other hand, we have found that some classes of oligomethylene-linked 6chlorotacrine-based hybrids can inhibit in a cell-based assay the aggregation of the two amyloidogenic proteins involved in $\mathrm{AD}$ pathogenesis, i.e. $\mathrm{A} \beta$ and tau [52]. Additionally, other families of hybrid compounds featuring a huprine moiety, closely related to 6chlorotacrine, as AChE inhibitor pharmacophore, have been shown to inhibit in vitro BACE-1, the enzyme that catalyzes the first and rate-limiting step of $A \beta$ production from the amyloid precursor protein (APP) $[53,63,64]$, with $\mathrm{IC}_{50}$ values ranging from nanomolar to low micromolar.

In the light of these findings, the presence in the novel hybrids of a 6-chlorotacrine unit and a benzohomoadamantanamine moiety, structurally related to memantine, prompted us to screen them for their potential inhibitory activity on $\mathrm{A} \beta$ and tau aggregation and BACE-1.

To assess the $A \beta$ and tau anti-aggregating activity of the hybrids, we used a cell-based assay in intact Escherichia coli cells that overexpress either $A \beta 42$, the most aggregation-prone and neurotoxic form of $\mathrm{A} \beta$, or tau, which upon expression form insoluble inclusion bodies that can be stained with thioflavin $\mathrm{S}[65,66]$. When tested at an inhibitor concentration of $10 \mu \mathrm{M}$, low percentages of inhibition were found both for A $\beta 42$ (up to $12 \%$ ) and for tau (up to $23 \%$ ) (Table 1), so these compounds are weak antiaggregating compounds. We had found very similar results in other tacrine- and 6chlorotacrine-based hybrids that feature a cycloaliphatic ring as the second pharmacophoric moiety [51], whereas much better anti-aggregating activities were found for 6-chlorotacrine- and huprine-based hybrids bearing as the second 
pharmacophore a polycyclic heteroaromatic system $[52,53,67]$. Thus, the presence of an extended aromatic system, apart from that of 6-chlorotacrine or huprine, seems to be a favourable structural requirement in this class of hybrid compounds for a good antiaggregating activity of $A \beta 42$, tau, and other amyloidogenic protein involved in other major human disorders [67].

Finally, we assessed the in vitro inhibitory activity of the novel hybrids towards human recombinant BACE-1, to find that they are essentially inactive or very weak inhibitors, with percentages of inhibition up to $18 \%$ at $5 \mu \mathrm{M}$. Even though the presence of a chlorotacrine unit, which should be mostly protonated in the acidic endosomal compartments where BACE-1 localizes, should enable a favourable salt bridge interaction with the aspartate residues of the catalytic dyad, the weak inhibitory activity of these hybrids should result from unfavourable secondary interactions of the benzohomoadamantane moiety within the large binding site of BACE-1.

\subsection{Brain permeation}

CNS drugs must be able to efficiently enter into the brain by crossing the blood-brain barrier (BBB). Hybrid compounds resulting from the pharmacophore combination approach tend to have rather large molecular weights, which might compromise their ability to cross biological membranes, including BBB $[68,69]$.

However, an increasing number of structurally diverse anti-Alzheimer hybrid compounds with molecular weights over 500 have shown good brain permeability in in vivo studies in mice [22]. As a preliminary assessment of brain permeability, the novel benzohomoadamantane-chlorotacrine hybrids were subjected to the parallel artificial membrane permeation assay-BBB (PAMPA-BBB), a well-established in vitro model of passive transcellular permeation [70]. In this method, the permeability $\left(P_{\mathrm{e}}\right)$ of the target compounds through a lipid extract of porcine brain is determined using a 70:30 mixture of phosphate-buffered saline (PBS)/EtOH. The assay was validated by correlating the experimental and reported $P_{\mathrm{e}}$ values of 14 known drugs (Section 4.2.5, Experimental Part). From the resulting linear correlation $\left[P_{\mathrm{e}}(\exp )=1.5758 P_{\mathrm{e}}(\mathrm{lit})-1.1459\left(\mathrm{R}^{2}=\right.\right.$ 0.9241)] and the limits established by Di et al. for BBB permeation [70], a threshold of $P_{\mathrm{e}}\left(10^{-6} \mathrm{~cm} \mathrm{~s}^{-1}\right)>5.2$ was set for compounds with high BBB permeation (CNS+), and thresholds of $P_{\mathrm{e}}\left(10^{-6} \mathrm{~cm} \mathrm{~s}^{-1}\right)<2.0$ and $5.2>P_{\mathrm{e}}\left(10^{-6} \mathrm{~cm} \mathrm{~s}^{-1}\right)>2.0$ were established for low (CNS-) and uncertain (CNS \pm ) BBB permeation, respectively. For the two hybrids that feature an unsubstituted bridgehead amino group, i.e. 18a and $\mathbf{1 8 b}$, an uncertain 
BBB permeation was predicted, whereas all the benzohomoadamantane-chlorotacrine hybrids of the first series, i.e. substituted at the bridgehead amino group, were predicted to be able to cross the BBB (Table 1), which anticipates their ability to enter the brain and reach their different CNS targets.

\section{Conclusion}

Molecular hybridization of the NMDA antagonist fluorobenzohomoadamantanamine 6 with the potent $\mathrm{AChE}$ inhibitor 6-chlorotacrine, 7, using a 4- and 5-carbon-atom tether chain attached at the bridgehead amino group or at an additional amino group on the benzene ring of the benzohomoadamantane core, has led to a new class of multitarget compounds that share the activities of the parent compounds on their primary targets. The effect of the different linkage position is apparent in $\mathrm{hBChE}$ inhibition, where hybrids that feature a memantine-like unsubstituted amino group are significantly more potent that those with the linker attached at that amino group. However, for hAChE inhibition and NMDA antagonism, the linkage position does not have a clear effect, with the potencies depending on tether length and/or the presence of a basic bridgehead nitrogen atom. The novel hybrids are particularly potent on hAChE (IC50 in the $0.33-1.96 \mathrm{nM}$ range) and then on $\mathrm{hBChE}$ ( $\mathrm{IC}_{50}$ in the $0.021-2.36 \mu \mathrm{M}$ range) and NMDA receptors ( $\mathrm{IC}_{50}$ in the $0.89-8.29 \mu \mathrm{M}$ range), but they seem to be devoid of activity on proteins other than their primary biological targets, showing weak inhibitory activity on $\mathrm{A} \beta 42$ and tau aggregation and BACE-1.

The increased potencies of all or some of the new hybrids relative to the parent compounds from which they were designed suggests that both pharmacophoric moieties are positively contributing to the interactions with all the primary targets. Indeed, all hybrids are clearly more potent hAChE inhibitors (up to 44-fold) than the parent 6chlorotacrine ( $\mathrm{IC}_{50} 14.5 \mathrm{nM}$ ), and some of them are also more potent for $\mathrm{hBChE}$ inhibition (up to 24-fold) than 6-chlorotacrine ( $\mathrm{IC}_{50} 0.50 \mu \mathrm{M}$ ) and up to 2-fold more potent NMDA antagonists than the parent fluorobenzohomoadamantanamine 6 (IC 50 $1.93 \mu \mathrm{M})$ and memantine ( $\left.\mathrm{IC}_{50} 1.50 \mu \mathrm{M}\right)$. Overall, the most interesting benzohomoadamantane-chlorotacrine hybrids, $\mathbf{1 3 b}, \mathbf{1 8 a}$, and $\mathbf{1 8 b}$ compare well with previously reported memantine- and amantadine- $\mathrm{AChE}$ inhibitor hybrids such as 3-5 (Figure 1), in terms of AChE inhibition and NMDA antagonism, and take on added value a nanomolar or submicromolar $\mathrm{hBChE}$ inhibitory activity, thereby constituting interesting leads for future multitarget anti-Alzheimer drug discovery programs. 


\section{Experimental part}

\subsection{Chemistry. General methods.}

All reagents were obtained from commercial suppliers (Sigma Aldrich, Acros, Cymit) unless otherwise stated, and used without further purification. The reactions were monitored by thin-layer chromatography (TLC) using aluminium-backed sheets with silica gel $60 \mathrm{~F}_{254}$ (Merck, ref 1.05554). The spots were visualized by UV irradiation and / or $1 \%$ aq. $\mathrm{KMnO}_{4}$, followed by charring with a heat-gun. Column chromatography was performed on silica gel 60 AC.C (35-70 mesh, SDS, ref 2000027). Melting points were determined in open capillary tubes with a MFB 595010M Gallenkamp melting point apparatus. IR spectra were run on a Perkin Elmer Spectrum RX I spectrophotometer. Absorption values are expressed as wavenumbers $\left(\mathrm{cm}^{-1}\right)$; only significant absorption bands are given. $400 \mathrm{MHz}{ }^{1} \mathrm{H} / 100.6 \mathrm{MHz}{ }^{13} \mathrm{C}$ NMR spectra were recorded on a Varian Mercury 400 spectrometer, at the Centres Científics i Tecnologics of the University of Barcelona (CCiTUB). The chemical shifts are reported in $\mathrm{ppm}(\delta$ scale) relative to solvent signals $\left(\mathrm{CD}_{3} \mathrm{OD}\right.$ at 3.31 and $49.0 \mathrm{ppm}$ in the ${ }^{1} \mathrm{H}$ and ${ }^{13} \mathrm{C} \mathrm{NMR}$ spectra, respectively; $\mathrm{CDCl}_{3}$ at 7.26 and $77.00 \mathrm{ppm}$ in the ${ }^{1} \mathrm{H}$ and ${ }^{13} \mathrm{C}$ NMR spectra, respectively), and coupling constants are reported in Hertz (Hz). Assignments given for the NMR spectra of the new compounds have been carried out by comparison with the NMR data of compounds $\mathbf{1 2 b}, \mathbf{1 3 b}$, and $\mathbf{1 8 b}$, which in turn, were assigned on the basis of COSY ${ }^{1} \mathrm{H} /{ }^{1} \mathrm{H}$ (standard procedures) and $\operatorname{COSY}{ }^{1} \mathrm{H} /{ }^{13} \mathrm{C}$ (gHSQC and gHMBC sequences) experiments. High resolution mass spectra were carried out at the CCiTUB with a LC/MSD TOF Agilent Technologies spectrometer.

\subsubsection{5-[(6-Chloro-1,2,3,4-tetrahydroacridin-9-yl)amino]-1-pentanol (9b)}

A mixture of 6,9-dichloro-1,2,3,4-tetrahydroacridine, 8 (1.50 g, $5.95 \mathrm{mmol})$ and 5amino-1-pentanol $(7.76 \mathrm{~mL}, 7.36 \mathrm{~g}, 71.3 \mathrm{mmol})$ was stirred at $135^{\circ} \mathrm{C}$ for 1 day. The mixture was cooled to room temperature, poured onto water $(200 \mathrm{~mL})$, diluted with $5 \mathrm{~N}$ $\mathrm{NaOH}(50 \mathrm{~mL})$, and extracted with EtOAc $(3 \times 100 \mathrm{~mL})$. The combined organic extracts were dried over anhydrous $\mathrm{Na}_{2} \mathrm{SO}_{4}$ and evaporated at reduced pressure, to give a dark brown oily residue $(2.50 \mathrm{~g})$, which was purified through column chromatography (35-70 $\mu \mathrm{m}$ silica gel, $\mathrm{CH}_{2} \mathrm{Cl}_{2} / \mathrm{MeOH} / 50 \%$ aq. $\mathrm{NH}_{4} \mathrm{OH}$ mixtures, gradient elution). On elution with $\mathrm{CH}_{2} \mathrm{Cl}_{2} / \mathrm{MeOH} / 50 \%$ aq. $\mathrm{NH}_{4} \mathrm{OH}$ 97:3:0.4, alcohol 9b (767 mg, 40\% yield) was isolated as a yellow solid; $R_{f} 0.32\left(\mathrm{CH}_{2} \mathrm{Cl}_{2} / \mathrm{MeOH} / 50 \%\right.$ aq. $\mathrm{NH}_{4} \mathrm{OH}$ $95: 5: 1)$. 
A solution of $9 \mathbf{b}(55 \mathrm{mg}, 0.17 \mathrm{mmol})$ in $\mathrm{CH}_{2} \mathrm{Cl}_{2}(1 \mathrm{~mL})$ was filtered through a $0.2 \mu \mathrm{m}$ PTFE filter, treated with a methanolic solution of $\mathrm{HCl}(0.5 \mathrm{M}, 1.0 \mathrm{~mL})$, and evaporated at reduced pressure. The solid was washed with pentane $(3 \times 2 \mathrm{~mL})$ to give, after drying at $65^{\circ} \mathrm{C} / 2$ Torr for $48 \mathrm{~h}, \mathbf{9 b} \cdot \mathrm{HCl}(61 \mathrm{mg})$ as a beige solid: $\mathrm{mp} 148-150{ }^{\circ} \mathrm{C}$; IR (ATR) $v$ 3400-2400 (max at 3250, 2924, 2859, O-H, N-H, ${ }^{+} \mathrm{N}-\mathrm{H}, \mathrm{C}-\mathrm{H}$ st), 1629, 1567, 1513 $(\mathrm{Ar}-\mathrm{C}-\mathrm{C}, \mathrm{Ar}-\mathrm{C}-\mathrm{N} \mathrm{st}) \mathrm{cm}^{-1} ;{ }^{1} \mathrm{H} \mathrm{NMR}\left(400 \mathrm{MHz}, \mathrm{CD}_{3} \mathrm{OD}\right) \delta 1.51\left(\mathrm{~m}, 2 \mathrm{H}, 3-\mathrm{H}_{2}\right), 1.67$ (m, 2H, 2- $\left.\mathrm{H}_{2}\right), 1.88\left(\mathrm{~m}, 2 \mathrm{H}, 4-\mathrm{H}_{2}\right), 1.92-2.20$ (m, 4H, 2'- $\left.\mathrm{H}_{2}, 3^{\prime}-\mathrm{H}_{2}\right), 2.68$ (t, $J=6.0 \mathrm{~Hz}$, $\left.2 \mathrm{H}, 1^{\prime}-\mathrm{H}_{2}\right), 3.00\left(\mathrm{t}, J=6.0 \mathrm{~Hz}, 2 \mathrm{H}, 4^{\prime}-\mathrm{H}_{2}\right), 3.57$ (t, $\left.J=6.4 \mathrm{~Hz}, 2 \mathrm{H}, 1-\mathrm{H}_{2}\right), 3.96$ (t, $J=$ $\left.7.2 \mathrm{~Hz}, 2 \mathrm{H}, 5-\mathrm{H}_{2}\right), 4.85$ (s, $\left.{ }^{+} \mathrm{NH}, \mathrm{NH}, \mathrm{OH}\right), 7.57$ (dd, $\left.J=9.2 \mathrm{~Hz}, J^{\prime}=2.0 \mathrm{~Hz}, 1 \mathrm{H}, 7^{\prime}-\mathrm{H}\right)$, $7.77\left(\mathrm{~d}, J=2.0 \mathrm{~Hz}, 1 \mathrm{H}, 5^{\prime}-\mathrm{H}\right), 8.40$ (d, $\left.J=9.2 \mathrm{~Hz}, 1 \mathrm{H}, 8^{\prime}-\mathrm{H}\right) ;{ }^{13} \mathrm{C}$ NMR (100.6 MHz, $\left.\mathrm{CD}_{3} \mathrm{OD}\right) \delta 21.8\left(\mathrm{CH}_{2}, \mathrm{C} 3{ }^{\prime}\right), 22.9\left(\mathrm{CH}_{2}, \mathrm{C} 2{ }^{\prime}\right), 24.1\left(\mathrm{CH}_{2}, \mathrm{C} 3\right), 24.7\left(\mathrm{CH}_{2}, \mathrm{C} 1^{\prime}\right), 29.3$ $\left(\mathrm{CH}_{2}, \mathrm{C}^{\prime}{ }^{\prime}\right), 31.1\left(\mathrm{CH}_{2}, \mathrm{C} 4\right), 33.0\left(\mathrm{CH}_{2}, \mathrm{C} 2\right), 48.8\left(\mathrm{CH}_{2}, \mathrm{C} 5\right), 62.6\left(\mathrm{CH}_{2}, \mathrm{C} 1\right), 113.4(\mathrm{C}$, C9a'), 115.4 (C, C8a'), 119.1 (CH, C5'), 126.8 (CH, C7'), 128.8 (CH, C8'), 140.1 (C, C6'), 140.5 (C, C10a'), 152.1 (C, C4a'), 157.9 (C, C9'); HRMS (ESI), calcd for $\left[\mathrm{C}_{18} \mathrm{H}_{23}{ }^{35} \mathrm{ClN} 2 \mathrm{O}+\mathrm{H}^{+}\right]$319.1578, found 319.1585 .

\subsubsection{5-[(6-Chloro-1,2,3,4-tetrahydroacridin-9-yl)amino]pentyl methanesulfonate (10b)}

A solution of alcohol 9b (368 mg, $1.15 \mathrm{mmol})$ and anhydrous $\mathrm{Et}_{3} \mathrm{~N}(0.27 \mathrm{~mL}, 197 \mathrm{mg}$, $1.95 \mathrm{mmol})$ in dry $\mathrm{CH}_{2} \mathrm{Cl}_{2}(7 \mathrm{~mL})$ was cooled at $-10{ }^{\circ} \mathrm{C}$ with an ice / $\mathrm{NaCl}$ bath, and, then, treated dropwise with methanesulfonyl chloride $(0.13 \mathrm{~mL}, 192 \mathrm{mg}, 1.68 \mathrm{mmol})$. The reaction mixture was stirred at $-10{ }^{\circ} \mathrm{C}$ for $30 \mathrm{~min}$ and concentrated in vacuo. The residue was taken up in $\mathrm{CH}_{2} \mathrm{Cl}_{2}(20 \mathrm{~mL})$, washed with $2 \mathrm{~N} \mathrm{NaOH}(3 \times 15 \mathrm{~mL})$, dried over anhydrous $\mathrm{Na}_{2} \mathrm{SO}_{4}$, and evaporated at reduced pressure, to afford mesylate $\mathbf{1 0 b}$ (461 mg, quantitative yield) as a dark brown oil; $R_{f} 0.72\left(\mathrm{CH}_{2} \mathrm{Cl}_{2} / \mathrm{MeOH} / 50 \%\right.$ aq. $\mathrm{NH}_{4} \mathrm{OH}$ 95:5:1).

A solution of $10 \mathrm{~b}(25 \mathrm{mg}, 0.06 \mathrm{mmol})$ in $\mathrm{CH}_{2} \mathrm{Cl}_{2}(1 \mathrm{~mL})$ was filtered through a $0.2 \mu \mathrm{m}$ PTFE filter and evaporated in vacuo. The resulting solid was washed with pentane $(3 \times 2 \mathrm{~mL})$, to afford, after drying at $65{ }^{\circ} \mathrm{C} / 2$ Torr for $48 \mathrm{~h}$, the analytical sample of 10b (24 mg) as a dark brown oil; IR (ATR) v $3286(\mathrm{~N}-\mathrm{H} \mathrm{st}), 1634,1604$, 1574, 1555 (Ar-C-C, Ar-C-N st) cm ${ }^{-1} ;{ }^{1} \mathrm{H}$ NMR (400 MHz, $\left.\mathrm{CDCl}_{3}\right) \delta 1.54$ (m, 2H, 3$\left.\mathrm{H}_{2}\right), 1.70-1.84\left(\mathrm{~m}, 4 \mathrm{H}, 2-\mathrm{H}_{2}, 4-\mathrm{H}_{2}\right), 1.86-1.93$ (m, 4H, 2'- $\left.\mathrm{H}_{2}, 3^{\prime}-\mathrm{H}_{2}\right), 2.67$ (t, 2H, 1'$\left.\mathrm{H}_{2}\right), 2.99$ (s, 3H, $\left.\mathrm{CH}_{3} \mathrm{SO}_{3}\right), 3.03\left(\mathrm{~m}, 2 \mathrm{H}, 4^{\prime}-\mathrm{H}_{2}\right), 3.58\left(\mathrm{~m}, 2 \mathrm{H}, 5-\mathrm{H}_{2}\right), 4.24$ (t, J=6.4 Hz, $\left.2 \mathrm{H}, 1-\mathrm{H}_{2}\right), 7.25\left(\mathrm{dd}, J=9.2 \mathrm{~Hz}, J^{\prime}=2.0 \mathrm{~Hz}, 1 \mathrm{H}, 7^{\prime}-\mathrm{H}\right), 7.88\left(\mathrm{~d}, J=2.0 \mathrm{~Hz}, 1 \mathrm{H}, 5^{\prime}-\mathrm{H}\right)$, 
$7.93\left(\mathrm{~d}, J=9.2 \mathrm{~Hz}, 1 \mathrm{H}, 8^{\prime}-\mathrm{H}\right) ;{ }^{13} \mathrm{C} \mathrm{NMR}\left(100.6 \mathrm{MHz}, \mathrm{CDCl}_{3}\right.$, this compound decomposed partially during acquisition of the spectrum, only some representative signals are given) $\delta 22.1\left(\mathrm{CH}_{2}\right), 22.7\left(\mathrm{CH}_{2}\right), 22.8\left(\mathrm{CH}_{2}\right)\left(\mathrm{C} 3, \mathrm{C}^{\prime}\right.$ ', $\mathrm{C} 3$ '), $24.7\left(\mathrm{CH}_{2}, \mathrm{C}^{\prime}\right)$, $28.8\left(\mathrm{CH}_{2}, \mathrm{C} 4\right), 30.9\left(\mathrm{CH}_{2}, \mathrm{C} 2\right), 32.6\left(\mathrm{CH}_{2}, \mathrm{C} 4\right), 37.4\left(\mathrm{CH}_{3}, \mathrm{OSO}_{2} \mathrm{CH}_{3}\right), 48.8\left(\mathrm{CH}_{2}\right.$, C5), 69.5 ( $\left.\mathrm{CH}_{2}, \mathrm{C} 1\right), 114.9$ (C, C9a'), 117.5 (C, C8a'), 151.7 (C, C4a'), 157.9 (C, C9'); HRMS (ESI), calcd for $\left[\mathrm{C}_{19} \mathrm{H}_{25}{ }^{35} \mathrm{ClN}_{2} \mathrm{O}_{3}+\mathrm{H}^{+}\right]$397.1347, found 397.1353.

\subsubsection{4-[(6-Chloro-1,2,3,4-tetrahydroacridin-9-yl)amino]butanenitrile (11a)}

A mixture of mesylate 10a [58] (2.32 g, $5.58 \mathrm{mmol})$ and $\mathrm{NaCN}(1.64 \mathrm{~g}, 33.5 \mathrm{mmol})$ in dry DMF $(5 \mathrm{~mL})$ was stirred at $100{ }^{\circ} \mathrm{C}$ for $1 \mathrm{~h}$, neutralized with $1 \mathrm{~N} \mathrm{NaOH}(50 \mathrm{~mL})$, and extracted with $\mathrm{CH}_{2} \mathrm{Cl}_{2}(4 \times 30 \mathrm{~mL})$. The combined organic extracts were washed with water $(6 \times 40 \mathrm{~mL})$, dried over anhydrous $\mathrm{Na}_{2} \mathrm{SO}_{4}$, and evaporated under reduced pressure, to give nitrile $11 \mathrm{a}\left(1.61 \mathrm{~g}, 98 \%\right.$ yield) as a brown oil; $R_{f} 0.68\left(\mathrm{CH}_{2} \mathrm{Cl}_{2} / \mathrm{MeOH}\right.$ / 50\% aq. $\mathrm{NH}_{4} \mathrm{OH}$ 95:5:1).

A solution of $11 \mathrm{a}(142 \mathrm{mg}, 0.47 \mathrm{mmol})$ in $\mathrm{CH}_{2} \mathrm{Cl}_{2}(1 \mathrm{~mL})$ was filtered through a $0.2 \mu \mathrm{m}$ PTFE filter, treated with a methanolic solution of $\mathrm{HCl}(0.5 \mathrm{M}, 0.8 \mathrm{~mL})$, and evaporated at reduced pressure. The solid was washed with pentane $(3 \times 2 \mathrm{~mL})$ to give, after drying at $65{ }^{\circ} \mathrm{C} / 2$ Torr for $48 \mathrm{~h}, \mathbf{1 1 a} \cdot \mathrm{HCl}(154 \mathrm{mg})$ as a brown solid: $\mathrm{mp} 114-116^{\circ} \mathrm{C}$; IR (ATR) v 3500-2500 (max at 3050, 2930, 2861, 2761, N-H, ${ }^{+} \mathrm{N}-\mathrm{H}, \mathrm{C}-\mathrm{H}$ st), 2232 (CN st), 1629, 1567, 1514 (Ar-C-C, Ar-C-N st) cm ${ }^{-1} ;{ }^{1} \mathrm{H}$ NMR (400 MHz, CD 30 OD) $\delta$ 1.92-2.02 (m, 4H, 2'- $\left.\mathrm{H}_{2}, 3^{\prime}-\mathrm{H}_{2}\right), 2.18$ (tt, $\left.J=J^{\prime}=7.2 \mathrm{~Hz}, 2 \mathrm{H}, 3-\mathrm{H}_{2}\right), 2.62$ (t, $J=7.2 \mathrm{~Hz}$, $\left.2 \mathrm{H}, 2-\mathrm{H}_{2}\right), 2.73\left(\mathrm{t}, J=6.0 \mathrm{~Hz}, 2 \mathrm{H}, 1^{\prime}-\mathrm{H}_{2}\right), 3.02\left(\mathrm{t}, J=5.6 \mathrm{~Hz}, 2 \mathrm{H}, 4^{\prime}-\mathrm{H}_{2}\right), 4.08(\mathrm{t}, J=$ $\left.7.2 \mathrm{~Hz}, 2 \mathrm{H}, 4-\mathrm{H}_{2}\right), 4.85\left(\mathrm{~s},{ }^{+} \mathrm{NH}, \mathrm{NH}\right), 7.58\left(\mathrm{dd}, J=9.2 \mathrm{~Hz}, J^{\prime}=2.0 \mathrm{~Hz}, 1 \mathrm{H}, 7^{\prime}-\mathrm{H}\right), 7.80$ $\left(\mathrm{d}, J=2.0 \mathrm{~Hz}, 1 \mathrm{H}, 5^{\prime}-\mathrm{H}\right), 8.39$ (d, $\left.J=9.2 \mathrm{~Hz}, 1 \mathrm{H}, 8^{\prime}-\mathrm{H}\right) ;{ }^{13} \mathrm{C} \mathrm{NMR}(100.6 \mathrm{MHz}$, $\left.\mathrm{CD}_{3} \mathrm{OD}\right) \delta 15.1\left(\mathrm{CH}_{2}, \mathrm{C} 2\right), 21.7\left(\mathrm{CH}_{2}, \mathrm{C} 3\right.$ ') $22.9\left(\mathrm{CH}_{2}, \mathrm{C}^{\prime}{ }^{\prime}\right), 25.0\left(\mathrm{CH}_{2}, \mathrm{C} 1\right.$ ') $), 27.1$ ( $\left.\mathrm{CH}_{2}, \mathrm{C} 3\right), 29.4\left(\mathrm{CH}_{2}, \mathrm{C}^{\prime}\right.$ '), 47.8 ( $\left.\mathrm{CH}_{2}, \mathrm{C} 4\right), 113.9$ (C, C9a'), 115.5 (C, C8a'), 119.2 (CH, C5'), 120.5 (C, C1), 127.1 (CH, C7'), 128.6 (CH, C8'), 140.2 (C, C6'), 140.4 (C, C10a'), 152.6 (C, C4a'), 157.9 (C, C9'); HRMS (ESI), calcd for $\left[\mathrm{C}_{17} \mathrm{H}_{18}{ }^{35} \mathrm{ClN}_{3}+\mathrm{H}^{+}\right]$ 300.1262 , found 300.1265 .

\subsubsection{5-[(6-Chloro-1,2,3,4-tetrahydroacridin-9-yl)amino]pentanenitrile (11b)}

A mixture of 6-chlorotacrine, $7(1.50 \mathrm{~g}, 6.45 \mathrm{mmol})$, finely powdered $\mathrm{KOH}(85 \%$ purity, $851 \mathrm{mg}, 12.9 \mathrm{mmol})$, and $4 \AA$ molecular sieves in dry DMSO $(20 \mathrm{~mL})$ was stirred, heating every $10 \mathrm{~min}$ with a heat gun for $1 \mathrm{~h}$, and at room temperature for 1 
additional $\mathrm{h}$, and it was then treated with 5-bromovaleronitrile $(0.9 \mathrm{~mL}, 1.25 \mathrm{~g}, 7.71$ $\mathrm{mmol})$. The reaction mixture was stirred at room temperature overnight, then diluted with $5 \mathrm{~N} \mathrm{NaOH}(350 \mathrm{~mL})$, and extracted with EtOAc $(3 \times 150 \mathrm{~mL})$. The combined organic extracts were washed with water $(3 \times 200 \mathrm{~mL})$, dried over anhydrous $\mathrm{Na}_{2} \mathrm{SO}_{4}$, and evaporated under reduced pressure, to give a yellow oily residue ( $2.28 \mathrm{~g})$, which was subjected to column chromatography purification (35-70 $\mu \mathrm{m}$ silica gel, $\mathrm{CH}_{2} \mathrm{Cl}_{2} /$ $50 \%$ aq. $\left.\mathrm{NH}_{4} \mathrm{OH} 100: 0.4\right)$, to afford nitrile $11 \mathrm{~b}$ (1.30 g, 64\% yield) as a light yellow solid; $R_{f} 0.73\left(\mathrm{CH}_{2} \mathrm{Cl}_{2} / \mathrm{MeOH} / 50 \%\right.$ aq. $\mathrm{NH}_{4} \mathrm{OH}$ 95:5:1).

A solution of $11 \mathbf{b}(21 \mathrm{mg}, 0.07 \mathrm{mmol})$ in $\mathrm{CH}_{2} \mathrm{Cl}_{2}(1 \mathrm{~mL})$ was filtered through a $0.2 \mu \mathrm{m}$ PTFE filter, treated with a methanolic solution of $\mathrm{HCl}(0.5 \mathrm{M}, 0.4 \mathrm{~mL})$, and evaporated at reduced pressure. The solid was washed with pentane $(3 \times 2 \mathrm{~mL})$ to give, after drying at $65^{\circ} \mathrm{C} / 2$ Torr for $48 \mathrm{~h}, \mathbf{1 1 b} \cdot \mathrm{HCl}\left(35 \mathrm{mg}\right.$ ) as a yellow solid: $\mathrm{mp} 73-75^{\circ} \mathrm{C}$; IR (ATR) $v$ 3500-2500 ( $\max$ at 3126, 3043, 2920, 2857, N-H, ${ }^{+} \mathrm{N}-\mathrm{H}, \mathrm{C}-\mathrm{H}$ st), 2236 (CN st), 1631, 1573, 1515 (Ar-C-C, Ar-C-N st) cm ${ }^{-1} ;{ }^{1} \mathrm{H}$ NMR (400 MHz, CD $\left.{ }_{3} \mathrm{OD}\right) \delta 1.78(\mathrm{~m}, 2 \mathrm{H}$, 3- $\left.\mathrm{H}_{2}\right), 1.92-2.02\left(\mathrm{~m}, 6 \mathrm{H}, 4-\mathrm{H}_{2}, 2^{\prime}-\mathrm{H}_{2}, 3\right.$ ' $\left.-\mathrm{H}_{2}\right), 2.54$ (t, $\left.J=6.0 \mathrm{~Hz}, 2 \mathrm{H}, 2-\mathrm{H}_{2}\right), 2.70$ (t, 2H, 1'- $\left.-\mathrm{H}_{2}\right), 3.00$ (t, 2H, 4'- $\left.-\mathrm{H}_{2}\right), 4.00$ (t, $\left.J=7.2 \mathrm{~Hz}, 2 \mathrm{H}, 5-\mathrm{H}_{2}\right), 4.85$ (s, $\left.{ }^{+} \mathrm{NH}, \mathrm{NH}\right), 7.57$ (dd, $J$ $\left.=9.2 \mathrm{~Hz}, J^{\prime}=2.0 \mathrm{~Hz}, 1 \mathrm{H}, 7^{\prime}-\mathrm{H}\right), 7.78$ (d, $\left.J=2.0 \mathrm{~Hz}, 1 \mathrm{H}, 5^{\prime}-\mathrm{H}\right), 8.39$ (d, $J=9.2 \mathrm{~Hz}, 1 \mathrm{H}$, $\left.8^{\prime}-\mathrm{H}\right) ;{ }^{13} \mathrm{C} \mathrm{NMR}\left(100.6 \mathrm{MHz}, \mathrm{CD}_{3} \mathrm{OD}\right) \delta 17.5\left(\mathrm{CH}_{2}, \mathrm{C} 2\right), 21.9\left(\mathrm{CH}_{2}, \mathrm{C} 3{ }^{\prime}\right), 23.0\left(\mathrm{CH}_{2}\right.$, C2'), $24.1\left(\mathrm{CH}_{2}, \mathrm{C} 3\right), 25.2\left(\mathrm{CH}_{2}, \mathrm{Cl}^{\prime}\right), 29.6\left(\mathrm{CH}_{2}, \mathrm{C}^{\prime}\right), 30.6\left(\mathrm{CH}_{2}, \mathrm{C} 4\right), 49.9\left(\mathrm{CH}_{2}\right.$, C5), 113.7 (C, C9a'), 115.6 (C, C8a'), 119.3 (CH, C5'), 120.9 (C, C1), 127.1 (CH, C7'), 128.9 (CH, C8'), 140.1 (C, C6'), 140.5 (C, C10a'), 152.4 (C, C4a'), 157.9 (C, C9'); HRMS (ESI), calcd for $\left[\mathrm{C}_{18} \mathrm{H}_{20}{ }^{35} \mathrm{ClN}_{3}+\mathrm{H}^{+}\right] 314.1419$, found 314.1416 .

\subsubsection{4-[(6-Chloro-1,2,3,4-tetrahydroacridin-9-yl)amino]- $\mathrm{N}$-(9-fluoro-7H-} 5,6,8,9,10,11-hexahydro-5,9:7,11-dimethanobenzo[9] annulen-7-yl)butanamide (12a) A solution of nitrile 11a $(1.53 \mathrm{~g}, 5.20 \mathrm{mmol})$ in $\mathrm{MeOH}(6.5 \mathrm{~mL})$ was treated with a $40 \%$ methanolic solution of $\mathrm{KOH}(13 \mathrm{~mL})$. The resulting suspension was stirred under reflux for $3 \mathrm{~h}$, then treated with water $(21 \mathrm{~mL})$, and again stirred under reflux overnight. The resulting solution was cooled to room temperature and evaporated in vacuo. The resulting residue was treated with $\mathrm{HCl} / \mathrm{Et}_{2} \mathrm{O}(0.73 \mathrm{~N}, 142 \mathrm{~mL})$, and the mixture was concentrated in vacuo to give the corresponding carboxylic acid in the form of hydrochloride salt (7.42 g), which was used in the following step without further purification. 
To a suspension of crude carboxylic acid ( $1.94 \mathrm{~g}$ of a crude that could contain a maximum of $1.36 \mathrm{mmol}$ of the carboxylic acid) in a mixture of EtOAc $(25 \mathrm{~mL})$ and DMF (2 mL), $N$-(3-dimethylaminopropyl)- $N$ '-ethylcarbodiimide hydrochloride (EDC hydrochloride) (316 mg, $1.65 \mathrm{mmol}), \mathrm{Et}_{3} \mathrm{~N}(0.94 \mathrm{~mL}, 685 \mathrm{mg}, 6.78 \mathrm{mmol})$, and 1hydroxy-1H-benzotriazole (HOBt) (185 mg, $1.36 \mathrm{mmol})$ were added. The resulting mixture was stirred at room temperature for $15 \mathrm{~min}$, and then treated with a suspension of amine 6 (346 mg, $1.50 \mathrm{mmol})$ in a mixture of EtOAc $(16 \mathrm{~mL})$ and DMF $(2 \mathrm{~mL})$. The reaction mixture was stirred at room temperature for 2 days, then concentrated in vacuo, diluted with $1 \mathrm{~N} \mathrm{NaOH}(200 \mathrm{~mL})$, and extracted with $\mathrm{CH}_{2} \mathrm{Cl}_{2}(2 \times 150 \mathrm{~mL})$. The combined organic extracts were washed with water $(5 \times 100 \mathrm{~mL})$, dried over anhydrous $\mathrm{Na}_{2} \mathrm{SO}_{4}$, and evaporated under reduced pressure to give a brown oil (696 mg), which was subjected to column chromatography purification (35-70 $\mu \mathrm{m}$ silica gel, $\mathrm{CH}_{2} \mathrm{Cl}_{2} /$ $\mathrm{MeOH} / 50 \%$ aq. $\mathrm{NH}_{4} \mathrm{OH}$ mixtures, gradient elution). On elution with $\mathrm{CH}_{2} \mathrm{Cl}_{2} / \mathrm{MeOH} /$ $50 \%$ aq. $\mathrm{NH}_{4} \mathrm{OH}$ 99.8:0.2:0.4, amide 12a (288 mg, 40\% yield) was isolated as a brown oil; $R_{f} 0.53\left(\mathrm{CH}_{2} \mathrm{Cl}_{2} / \mathrm{MeOH} / 50 \%\right.$ aq. $\mathrm{NH}_{4} \mathrm{OH}$ 95:5:1).

A solution of $12 \mathrm{a}(26 \mathrm{mg}, 0.05 \mathrm{mmol})$ in $\mathrm{CH}_{2} \mathrm{Cl}_{2}(1 \mathrm{~mL})$ was filtered through a $0.2 \mu \mathrm{m}$ PTFE filter, treated with a methanolic solution of $\mathrm{HCl}(0.5 \mathrm{M}, 0.3 \mathrm{~mL})$, and evaporated at reduced pressure. The solid was washed with pentane $(3 \times 2 \mathrm{~mL})$ to give, after drying at $65{ }^{\circ} \mathrm{C} / 2$ Torr for $48 \mathrm{~h}, \mathbf{1 2 a} \cdot \mathrm{HCl}(27 \mathrm{mg})$ as a yellow solid: $\mathrm{mp} 169-173{ }^{\circ} \mathrm{C}$; IR (ATR) v 3500-2400 (max at 3246, 3054, 2917, 2852, 2795, N-H, ${ }^{+} \mathrm{N}-\mathrm{H}, \mathrm{C}-\mathrm{H}$ st), 1631, 1584, $1574(\mathrm{C}=\mathrm{O}, \mathrm{Ar}-\mathrm{C}-\mathrm{C}, \mathrm{Ar}-\mathrm{C}-\mathrm{N} \mathrm{st}) \mathrm{cm}^{-1} ;{ }^{1} \mathrm{H}$ NMR (400 MHz, CD $\left.{ }_{3} \mathrm{OD}\right) \delta 1.80$ [br

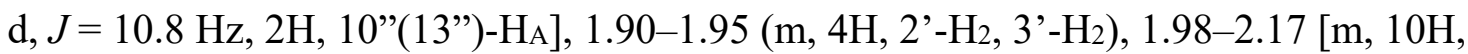

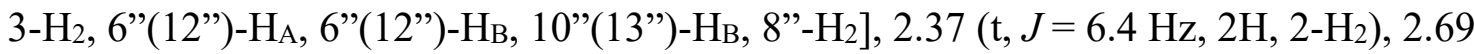

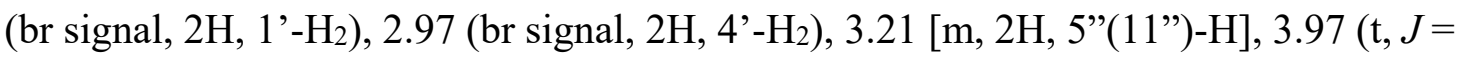
$\left.6.4 \mathrm{~Hz}, 2 \mathrm{H}, 4-\mathrm{H}_{2}\right), 4.86$ (s, $\left.{ }^{+} \mathrm{NH}, \mathrm{NH}\right), 7.06-7.14$ [m, 4H, 1"(4”)-H, 2"(3")-H], 7.49 (dd, $\left.J=9.2 \mathrm{~Hz}, J^{\prime}=2.0 \mathrm{~Hz}, 1 \mathrm{H}, 7^{\prime}-\mathrm{H}\right), 7.75\left(\mathrm{~d}, J=2.0 \mathrm{~Hz}, 1 \mathrm{H}, 5^{\prime}-\mathrm{H}\right), 8.41$ (d, $J=9.2 \mathrm{~Hz}$, 1H, 8'-H); ${ }^{13} \mathrm{C}$ NMR (100.6 MHz, $\left.\mathrm{CD}_{3} \mathrm{OD}\right) \delta 21.8\left(\mathrm{CH}_{2}, \mathrm{C}^{\prime}\right.$ '), $22.8\left(\mathrm{CH}_{2}, \mathrm{C} 2\right.$ '), 25.0 $\left(\mathrm{CH}_{2}, \mathrm{Cl}^{\prime}\right), 26.5\left(\mathrm{CH}_{2}, \mathrm{C} 3\right), 29.3\left(\mathrm{CH}_{2}, \mathrm{C}^{\prime}\right), 34.8\left(\mathrm{CH}_{2}, \mathrm{C} 2\right), 39.3\left[\mathrm{CH}_{2}, \mathrm{~d}, J_{C-F}=1.3\right.$ $\mathrm{Hz}, \mathrm{C6}$ "(12”)], 40.9 [CH, d, $\left.J_{C-F}=12.9 \mathrm{~Hz}, \mathrm{C} 5 ”(11 ”)\right], 41.3\left[\mathrm{CH}_{2}, \mathrm{~d}, J_{C-F}=20.0 \mathrm{~Hz}\right.$, C10”(13”)], $46.9\left(\mathrm{CH}_{2}, \mathrm{~d}, J_{C-F}=18.1 \mathrm{~Hz}, \mathrm{C} 8 ”\right), 49.3\left(\mathrm{CH}_{2}, \mathrm{C} 4\right), 58.8\left(\mathrm{C}, \mathrm{d}, J_{C-F}=11.0\right.$ Hz, C7’), 94.7 (C, d, JC-F $=176.8$ Hz, C9”), 113.4 (C, C9a'), 115.4 (C, C8a'), 119.0 (CH, C5'), 126.7 (CH, C7'), 128.0 [CH, C2”(3”)], 129.0 (CH, C8'), 129.1 [CH, C1”(4”)], 140.1 (C, C6'), 140.5 (C, C10a'), 146.2 [C, C4a”(11a”)], 151.9 (C, C4a'), 
157.9 (C, C9'), 174.4 (C, C1); HRMS (ESI), calcd for $\left[\mathrm{C}_{32} \mathrm{H}_{35}{ }^{35} \mathrm{ClFN}_{3} \mathrm{O}+\mathrm{H}^{+}\right]$ 532.2525 , found 532.2525 .

\subsubsection{5-[(6-Chloro-1,2,3,4-tetrahydroacridin-9-yl)amino]-N-(9-fluoro-7H-} 5,6,8,9,10,11-hexahydro-5,9:7,11-dimethanobenzo[9]annulen-7-yl)pentanamide (12b) This compound was prepared as described for 12a. From nitrile 11b (1.24 g, 4.04 mmol), crude carboxylic acid (6.17 g) was obtained as the hydrochloride salt and used in the following step without further purification. From crude carboxylic acid $(1.21 \mathrm{~g}$ of a crude that could contain a maximum of $0.79 \mathrm{mmol}$ of carboxylic acid) and amine 6 (200 $\mathrm{mg}, 0.87 \mathrm{mmol}$ ), a brown solid residue (1.87 g) was obtained and subjected to column chromatography purification (35-70 $\mu \mathrm{m}$ silica gel, $\mathrm{CH}_{2} \mathrm{Cl}_{2} / \mathrm{MeOH} / 50 \%$ aq. $\mathrm{NH}_{4} \mathrm{OH}$ mixtures, gradient elution). On elution with $\mathrm{CH}_{2} \mathrm{Cl}_{2} / \mathrm{MeOH} / 50 \%$ aq. $\mathrm{NH}_{4} \mathrm{OH}$ 99:1:0.4 to $98.5: 1.5: 0.4$, amide $\mathbf{1 2 b}$ (324 $\mathrm{mg}, 75 \%$ yield) was isolated as a yellow oil; $R_{f}$ $0.61\left(\mathrm{CH}_{2} \mathrm{Cl}_{2} / \mathrm{MeOH} / 50 \%\right.$ aq. $\mathrm{NH}_{4} \mathrm{OH}$ 95:5:1).

A solution of $12 \mathbf{b}(36 \mathrm{mg}, 0.07 \mathrm{mmol})$ in $\mathrm{CH}_{2} \mathrm{Cl}_{2}(1 \mathrm{~mL})$ was filtered through a $0.2 \mu \mathrm{m}$ PTFE filter, treated with a methanolic solution of $\mathrm{HCl}(0.5 \mathrm{M}, 0.4 \mathrm{~mL})$, and evaporated at reduced pressure. The solid was washed with pentane $(3 \times 2 \mathrm{~mL})$ to give, after drying at $65^{\circ} \mathrm{C} / 2$ Torr for $48 \mathrm{~h}, \mathbf{1 2 b} \cdot \mathrm{HCl}(38 \mathrm{mg})$ as a yellow solid: $\mathrm{mp} 181-185^{\circ} \mathrm{C}$; IR (ATR) v 3500-2500 (max at 3193, 3126, 3043, 2915, 2857, N-H, ${ }^{+} \mathrm{N}-\mathrm{H}, \mathrm{C}-\mathrm{H}$ st), 1632, 1589, $1571(\mathrm{C}=\mathrm{O}, \mathrm{Ar}-\mathrm{C}-\mathrm{C}, \mathrm{Ar}-\mathrm{C}-\mathrm{N} \mathrm{st}) \mathrm{cm}^{-1} ;{ }^{1} \mathrm{H}$ NMR $\left(400 \mathrm{MHz}, \mathrm{CD}_{3} \mathrm{OD}\right) \delta 1.68(\mathrm{~m}$,

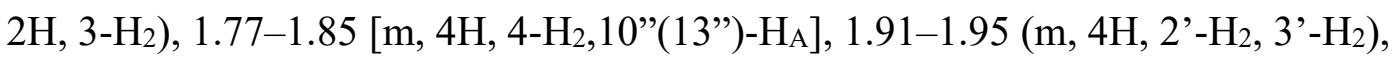

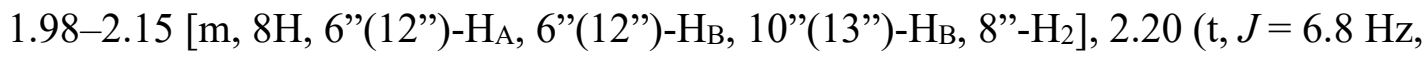
2H, 2- $\mathrm{H}_{2}$ ), 2.67 (br signal, 2H, 1'- $\mathrm{H}_{2}$ ), 2.98 (br signal, 2H, 4'- $\mathrm{H}_{2}$ ), 3.20 [m, 2H, 5"(11")$\mathrm{H}], 3.94$ (t, $\left.J=6.8 \mathrm{~Hz}, 2 \mathrm{H}, 5-\mathrm{H}_{2}\right), 4.85$ (s, $\left.{ }^{+} \mathrm{NH}, \mathrm{NH}\right), 7.06-7.13$ [m, 4H, 1"(4”)-H, 2”(3”)-H], 7.53 (dd, $J=9.2 \mathrm{~Hz}, J^{\prime}=2.4 \mathrm{~Hz}, 1 \mathrm{H}, 7$ '-H), 7.76 (d, $J=2.4 \mathrm{~Hz}, 1 \mathrm{H}, 5$ '-H), $8.39\left(\mathrm{~d}, J=9.2 \mathrm{~Hz}, 1 \mathrm{H}, 8^{\prime}-\mathrm{H}\right) ;{ }^{13} \mathrm{C} \mathrm{NMR}\left(100.6 \mathrm{MHz}, \mathrm{CD}_{3} \mathrm{OD}\right) \delta 21.7\left(\mathrm{CH}_{2}, \mathrm{C} 3\right.$ '), 22.8 $\left(\mathrm{CH}_{2}, \mathrm{C} 2\right.$ ') $), 23.6\left(\mathrm{CH}_{2}, \mathrm{C} 3\right), 24.8\left(\mathrm{CH}_{2}, \mathrm{Cl}^{\prime}\right), 29.3\left(\mathrm{CH}_{2}, \mathrm{C}^{\prime}\right), 30.5\left(\mathrm{CH}_{2}, \mathrm{C} 4\right), 36.7$ $\left(\mathrm{CH}_{2}, \mathrm{C} 2\right), 39.3\left[\mathrm{CH}_{2}, \mathrm{~d}, J_{C-F}=2.0 \mathrm{~Hz}, \mathrm{C} 6 "(12 ”)\right], 40.9\left[\mathrm{CH}, \mathrm{d}, J_{C-F}=12.9 \mathrm{~Hz}\right.$, C5"(11”)], $41.3\left[\mathrm{CH}_{2}, \mathrm{~d}, J_{C-F}=20.0 \mathrm{~Hz}, \mathrm{C} 10 ”(13 ”)\right], 46.8\left(\mathrm{CH}_{2}, \mathrm{~d}, J_{C-F}=18.1 \mathrm{~Hz}, \mathrm{C} 8 ”\right)$, $48.8\left(\mathrm{CH}_{2}, \mathrm{C} 5\right), 58.7$ (C, d, $J_{C-F}=11.6 \mathrm{~Hz}, \mathrm{C} 7$ '), 94.7 (C, d, $\left.J_{C-F}=176.8 \mathrm{~Hz}, \mathrm{C} 9 ”\right)$, 113.5 (C, C9a'), 115.5 (C, C8a'), 119.1 (CH, C5'), 126.8 (CH, C7'), 128.0 [CH, C2”(3”)], 128.8 (CH, C8'), 129.1 [CH, C1"(4”)], 140.1 (C, C6'), 140.5 (C, C10a'), 
146.2 [C, C4a”(11a”)], 152.1 (C, C4a'), 157.8 (C, C9'), 174.8 (C, C1); HRMS (ESI), calcd for $\left[\mathrm{C}_{33} \mathrm{H}_{37}{ }^{35} \mathrm{ClFN}_{3} \mathrm{O}+\mathrm{H}^{+}\right]$546.2682, found 546.2685.

4.1.7. N-(6-Chloro-1,2,3,4-tetrahydroacridin-9-yl)-N'-(9-fluoro-7H-5,6,8,9,10,11hexahydro-5,9:7,11-dimethanobenzo[9] annulen-7-yl)-1,4-butanediamine (13a) A solution of amide 12a $(124 \mathrm{mg}, 0.22 \mathrm{mmol})$ in dry THF $(5 \mathrm{~mL})$ was cooled to $0{ }^{\circ} \mathrm{C}$ with an ice bath, and then treated dropwise with $\mathrm{BH}_{3} \cdot \mathrm{THF}(1 \mathrm{M}$ in THF, $0.87 \mathrm{~mL}, 0.87$ $\mathrm{mmol})$. The reaction mixture was stirred at room temperature overnight. The resulting mixture was cooled to $0{ }^{\circ} \mathrm{C}$, and treated dropwise with $\mathrm{MeOH}(3 \mathrm{~mL})$ and water $(3 \mathrm{~mL})$. The organic phase was evaporated under reduced pressure, and the aqueous phase was diluted with $1 \mathrm{~N} \mathrm{NaOH}(10 \mathrm{~mL})$ and extracted with $\mathrm{CH}_{2} \mathrm{Cl}_{2}(3 \times 10 \mathrm{~mL})$. The combined organic extracts were dried over anhydrous $\mathrm{Na}_{2} \mathrm{SO}_{4}$ and evaporated in vacuo, to give a beige solid residue $(111 \mathrm{mg})$, which was subjected to column chromatography purification (35-70 $\mu \mathrm{m}$ silica gel, hexane / EtOAc / 50\% aq. $\mathrm{NH}_{4} \mathrm{OH}$ mixtures, gradient elution). On elution with hexane / EtOAc / 50\% aq. $\mathrm{NH}_{4} \mathrm{OH}$ 50:50:0.4, starting 12a (41 $\mathrm{mg}$ ) was recovered. On elution with hexane / EtOAc / 50\% aq. $\mathrm{NH}_{4} \mathrm{OH}$ 40:60:0.4, amine 13a (27 mg, 24\% yield) was isolated as a yellow sticky solid; $R_{f} 0.45\left(\mathrm{CH}_{2} \mathrm{Cl}_{2} /\right.$ $\mathrm{MeOH} / 50 \%$ aq. $\mathrm{NH}_{4} \mathrm{OH}$ 95:5:1).

A solution of 13a $(27 \mathrm{mg}, 0.05 \mathrm{mmol})$ in $\mathrm{CH}_{2} \mathrm{Cl}_{2}(1 \mathrm{~mL})$ was filtered through a $0.2 \mu \mathrm{m}$ PTFE filter, treated with a methanolic solution of $\mathrm{HCl}(0.5 \mathrm{M}, 0.3 \mathrm{~mL})$, and evaporated at reduced pressure. The solid was washed with pentane $(3 \times 2 \mathrm{~mL})$ and recrystallized from $\mathrm{MeOH} /$ EtOAc 1:1 (1 mL), to give, after drying at $65^{\circ} \mathrm{C} / 2$ Torr for $48 \mathrm{~h}$, the analytical sample of $13 \mathrm{a} \cdot 2 \mathrm{HCl}(7 \mathrm{mg})$, as a pale yellow solid: ${ }^{1} \mathrm{H} \mathrm{NMR}(400 \mathrm{MHz}$, $\left.\mathrm{CD}_{3} \mathrm{OD}\right) \delta 1.81\left(\mathrm{~m}, 2 \mathrm{H}, 2-\mathrm{H}_{2}\right), 1.86-2.03$ (m, 10H, 3- $\mathrm{H}_{2}, 2$ '- $\mathrm{H}_{2}, 3$ '- $\mathrm{H}_{2}, 6$ '”(12”)- $\mathrm{H}_{\mathrm{A}}$,

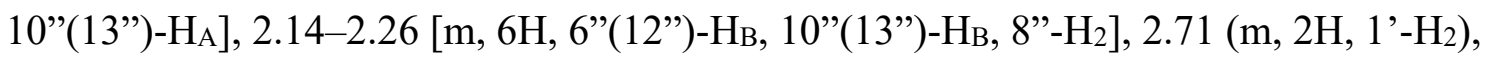
3.00 (m, 2H, 4'- $\left.\mathrm{H}_{2}\right), 3.08$ (t, $\left.J=7.6 \mathrm{~Hz}, 2 \mathrm{H}, 1-\mathrm{H}_{2}\right), 3.41$ [m, 2H, 5"(11”)-H], 4.01 (t, $J=$ $\left.7.2 \mathrm{~Hz}, 2 \mathrm{H}, 4-\mathrm{H}_{2}\right), 4.85$ (s, $\left.{ }^{+} \mathrm{NH}, \mathrm{NH}\right), 7.16$ [m, 4H, 1"(4”)-H, 2"(3”)-H], 7.58 (dd, $J=$ $\left.8.8 \mathrm{~Hz}, J^{\prime}=2.0 \mathrm{~Hz}, 1 \mathrm{H}, 7^{\prime}-\mathrm{H}\right), 7.77$ (d, $\left.J=2.0 \mathrm{~Hz}, 1 \mathrm{H}, 5^{\prime}-\mathrm{H}\right), 8.41$ (d, $J=8.8 \mathrm{~Hz}, 1 \mathrm{H}$, $\left.8^{\prime}-\mathrm{H}\right) ;{ }^{13} \mathrm{C}$ NMR (100.6 MHz, CD $\left.3 \mathrm{OD}\right) \delta 21.7\left(\mathrm{CH}_{2}, \mathrm{C} 3\right.$ '), $22.9\left(\mathrm{CH}_{2}, \mathrm{C} 2\right.$ '), $24.9\left(\mathrm{CH}_{2}\right.$, C1'), $25.1\left(\mathrm{CH}_{2}, \mathrm{C} 3\right), 28.5\left(\mathrm{CH}_{2}, \mathrm{C} 2\right), 29.4\left(\mathrm{CH}_{2}, \mathrm{C} 4\right.$ '), 36.6 [CH $2, \mathrm{C} 6$ ”(12”)], 40.0 [CH, d, $\left.J_{C-F}=13.1 \mathrm{~Hz}, \mathrm{C} 5 "\left(11^{\prime \prime}\right)\right], 40.7\left[\mathrm{CH}_{2}, \mathrm{~d}, J_{C-F}=20.1 \mathrm{~Hz}, \mathrm{C} 10 "\left(13\right.\right.$ ”)], $41.2\left(\mathrm{CH}_{2}, \mathrm{C} 1\right)$, $44.4\left(\mathrm{CH}_{2}, \mathrm{~d}, J_{C-F}=21.1 \mathrm{~Hz}, \mathrm{C} 8\right.$ ”), $49.7\left(\mathrm{CH}_{2}, \mathrm{C} 4\right), 63.8$ (C, d, $\left.J_{C-F}=11.1 \mathrm{~Hz}, \mathrm{C} 7 ”\right)$, 94.2 (C, d, $J_{C-F}=180.1 \mathrm{~Hz}, \mathrm{C} 9$ ”), 113.8 (C, C9a'), 115.6 (C, C8a'), 119.2 (CH, C5'), 127.0 (CH, C7'), 128.6 [CH, C2"(3")], 128.7 (CH, C8'), 129.4 [CH, C1”(4”)], 140.1 (C, 
C6'), 140.6 (C, C10a'), 145.1 [C, C4a"(11a”)], 152.5 (C, C4a'), 157.9 (C, C9'); HRMS (ESI), calcd for $\left[\mathrm{C}_{32} \mathrm{H}_{37}{ }^{35} \mathrm{ClFN}_{3}+\mathrm{H}^{+}\right]$518.2733, found 518.2710.

4.1.8. N-(6-Chloro-1,2,3,4-tetrahydroacridin-9-yl)-N'-(9-fluoro-7H-5,6,8,9,10,11hexahydro-5,9:7,11-dimethanobenzo[9]annulen-7-yl)-1,5-pentanediamine (13b) 4.1.8.1. From 12b. This compound was prepared as decribed for 13a. From amide 12b (100 $\mathrm{mg}, 0.18 \mathrm{mmol})$, an orange solid residue $(79 \mathrm{mg}$ ) was obtained and subjected to column chromatography purification $\left(35-70 \mu \mathrm{m}\right.$ silica gel, hexane / EtOAc / $\mathrm{Et}_{3} \mathrm{~N}$ mixtures, gradient elution). On elution with hexane / EtOAc / $\mathrm{Et}_{3} \mathrm{~N}$ 30:70:0.2, amine 13b (10 mg, 10\% yield) was isolated as a yellow solid; $R_{f} 0.45\left(\mathrm{CH}_{2} \mathrm{Cl}_{2} / \mathrm{MeOH} / 50 \%\right.$ aq. $\mathrm{NH}_{4} \mathrm{OH}$ 95:5:1).

A solution of $\mathbf{1 3 b}(10 \mathrm{mg}, 0.02 \mathrm{mmol})$ in $\mathrm{CH}_{2} \mathrm{Cl}_{2}(1 \mathrm{~mL})$ was filtered through a $0.2 \mu \mathrm{m}$ PTFE filter, treated with a methanolic solution of $\mathrm{HCl}(1.35 \mathrm{M}, 0.13 \mathrm{~mL})$, and evaporated at reduced pressure. The solid was washed with pentane $(3 \times 2 \mathrm{~mL})$, to give, after drying at $65{ }^{\circ} \mathrm{C} / 2$ Torr for $48 \mathrm{~h}$, the analytical sample of $\mathbf{1 3 b} \cdot 2 \mathrm{HCl}(12 \mathrm{mg})$, as a yellow solid: ${ }^{1} \mathrm{H}$ NMR (400 MHz, CD $\left.3 \mathrm{OD}\right) \delta 1.55\left(\mathrm{tt}, J=J^{\prime}=7.6 \mathrm{~Hz}, 2 \mathrm{H}, 3-\mathrm{H}_{2}\right.$ ), 1.77 (tt, $\left.J=J^{\prime}=7.6 \mathrm{~Hz} 2 \mathrm{H}, 2-\mathrm{H}_{2}\right), 1.85-1.99$ [m, 10H, 4- $\mathrm{H}_{2}, 2^{\prime}-\mathrm{H}_{2}, 3^{\prime}-\mathrm{H}_{2}, 6$ '”(12”)- $\mathrm{H}_{\mathrm{A}}$,

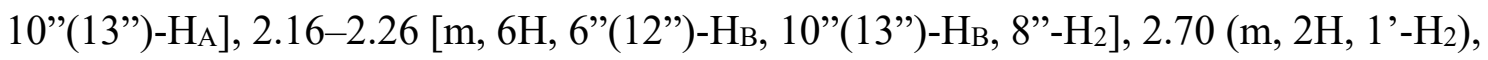
3.00 (m, 2H, 4'- $\left.-\mathrm{H}_{2}\right), 3.04$ (t, $\left.J=7.6 \mathrm{~Hz}, 2 \mathrm{H}, 1-\mathrm{H}_{2}\right), 3.41$ [m, 2H, 5’(11”)-H], 3.97 (t, $J=$ $\left.7.6 \mathrm{~Hz}, 2 \mathrm{H}, 5-\mathrm{H}_{2}\right), 4.85$ (s, $\left.{ }^{+} \mathrm{NH}, \mathrm{NH}\right), 7.15$ [m, 4H, 1"(4”)-H, 2"(3”)-H], 7.57 (dd, $J=$ $\left.9.6 \mathrm{~Hz}, J^{\prime}=2.0 \mathrm{~Hz}, 1 \mathrm{H}, 7^{\prime}-\mathrm{H}\right), 7.78\left(\mathrm{~d}, J=2.0 \mathrm{~Hz}, 1 \mathrm{H}, 5^{\prime}-\mathrm{H}\right), 8.41$ (d, $J=9.6 \mathrm{~Hz}, 1 \mathrm{H}$, $\left.8^{\prime}-\mathrm{H}\right) ;{ }^{13} \mathrm{C}$ NMR (100.6 MHz, CD $\left.3 \mathrm{OD}\right) \delta 21.7\left(\mathrm{CH}_{2}, \mathrm{C}^{\prime}\right.$ '), $22.9\left(\mathrm{CH}_{2}, \mathrm{C} 2\right.$ '), $24.8(2$ $\mathrm{CH}_{2}, \mathrm{Cl}$ ', C3), $27.4\left(\mathrm{CH}_{2}, \mathrm{C} 2\right), 29.3\left(\mathrm{CH}_{2}, \mathrm{C} 4\right.$ '), $30.8\left(\mathrm{CH}_{2}, \mathrm{C} 4\right), 36.5$ [CH $2, \mathrm{C6}$ '(12")], 40.0 [CH, d, $J_{C-F}=13.0 \mathrm{~Hz}, \mathrm{C} 5 ”\left(11\right.$ ”)], 40.7 [CH2, d, $\left.J_{C-F}=20.6 \mathrm{~Hz}, \mathrm{C} 10 ”(13 ”)\right], 41.3$ $\left(\mathrm{CH}_{2}, \mathrm{C} 1\right), 44.3\left(\mathrm{CH}_{2}, \mathrm{~d}, J_{C-F}=20.7 \mathrm{~Hz}, \mathrm{C} 8 ”\right), 49.2\left(\mathrm{CH}_{2}, \mathrm{C} 5\right), 63.7\left(\mathrm{C}, \mathrm{d}, J_{C-F}=11.0\right.$ Hz, C7”), 94.2 (C, d, JC-F $=180.0$ Hz, C9”), 113.5 (C, C9a'), 115.5 (C, C8a'), 119.1 (CH, C5'), 126.9 (CH, C7'), 128.5 [CH, C2”(3”)], 128.8 (CH, C8'), 129.4 [CH, C1”(4”)], 140.1 (C, C6'), 140.5 (C, C10a'), 145.2 [C, C4a”(11a”)], 152.2 (C, C4a'), 157.9 (C, C9'); HRMS (ESI), calcd for $\left[\mathrm{C}_{33} \mathrm{H}_{39}{ }^{35} \mathrm{ClFN}_{3}+\mathrm{H}^{+}\right] 532.2889$, found 532.2906 .

4.1.8.2. From 10b. A solution of mesylate $10 b(237 \mathrm{mg}, 0.60 \mathrm{mmol})$ in DMF (1.5 mL) was added to a stirred suspension of amine $6(115 \mathrm{mg}, 0.42 \mathrm{mmol})$ and $\mathrm{K}_{2} \mathrm{CO}_{3}(130 \mathrm{mg}$, $0.94 \mathrm{mmol}$ ) in DMF. The reaction mixture was stirred at $80^{\circ} \mathrm{C}$ for 2 days and then it was concentrated in vacuo. The resulting residue was taken up in water $(15 \mathrm{~mL})$ and $2 \mathrm{~N}$ 
$\mathrm{NaOH}(15 \mathrm{~mL})$, and extracted with $\mathrm{CH}_{2} \mathrm{Cl}_{2}(3 \times 20 \mathrm{~mL})$. The combined organic extracts were dried over anhydrous $\mathrm{Na}_{2} \mathrm{SO}_{4}$ and evaporated at reduced pressure, to give a dark brown oil (309 mg), which was subjected to column chromatography purification (35-70 $\mu \mathrm{m}$ silica gel, $\mathrm{CH}_{2} \mathrm{Cl}_{2} / \mathrm{MeOH} / 50 \%$ aq. $\mathrm{NH}_{4} \mathrm{OH}$ mixtures, gradient elution). On elution with $\mathrm{CH}_{2} \mathrm{Cl}_{2} / \mathrm{MeOH} / 50 \%$ aq. $\mathrm{NH}_{4} \mathrm{OH}$ 98.6:1.4:0.4, byproduct 6-chloro-9-(5chloropentylamino)-1,2,3,4-tetrahydroacridine (38 mg) was isolated. On elution with $\mathrm{CH}_{2} \mathrm{Cl}_{2} / \mathrm{MeOH} / 50 \%$ aq. $\mathrm{NH}_{4} \mathrm{OH}$ 97:3:0.4, an inseparable 1.5:1 mixture of the desired amide 13b and byproduct 5-[(6-chloro-1,2,3,4-tetrahydroacridin-9-yl)amino]-1-pentanol ( $86 \mathrm{mg}, 27 \%$ yield of $\mathbf{1 3 b}$ ) was obtained.

\subsection{9. tert-Butyl (9-fluoro-7H-5,6,8,9,10,11-hexahydro-2-nitro-5,9:7,11-} dimethanobenzo[9]annulen-7-yl)carbamate (15)

To a mixture of amine 14 [59] (496 mg, $1.79 \mathrm{mmol}$ ) and 2N NaOH (1.4 mL) in THF (3.5 mL), di-tert-butyl dicarbonate $(355 \mathrm{mg}, 1.62 \mathrm{mmol})$ was added. The reaction mixture was stirred at room temperature for $16 \mathrm{~h}$, then cooled in an ice bath, neutralized with $2 \mathrm{~N} \mathrm{HCl}$, and extracted with EtOAc. The combined organic extracts were dried over anhydrous $\mathrm{Na}_{2} \mathrm{SO}_{4}$ and evaporated in vacuo, to give the $\mathrm{N}$-Boc protected amine $\mathbf{1 5}$ (589 mg, 87\% yield): $\mathrm{mp} 204-205^{\circ} \mathrm{C}$; IR ( NaCl) v 3426 (N-H st), 1725, 1714 (C=O st), 1608, 1588, 1520, $1505\left(\mathrm{NO}_{2}\right.$ st as), 1391, 1360, 1345, 1306, $1285\left(\mathrm{NO}_{2} \mathrm{st} \mathrm{s}\right) \mathrm{cm}^{-1} ;{ }^{1} \mathrm{H}$ NMR $\left(400 \mathrm{MHz}, \mathrm{CDCl}_{3}\right) \delta 1.41\left[\mathrm{~s}, 9 \mathrm{H}, \mathrm{C}\left(\mathrm{CH}_{3}\right)_{3}\right], 1.88-2.24$ (m, 10H, methylene protons), 3.37 (m, 2H, 5-H, 11-H), 4.58 (br.s., 1H, NHCOO), 7.25 (dd, $J=7.2 \mathrm{~Hz}, J^{\prime}=$ $2.0 \mathrm{~Hz}, 1 \mathrm{H}, 3-\mathrm{H}), 7.97-8.00$ (m, 2H, 1-H, 4-H); ${ }^{13} \mathrm{C} \mathrm{NMR}\left(100.6 \mathrm{MHz}, \mathrm{CDCl}_{3}\right) \delta 28.5$ $\left[\mathrm{CH}_{3}, \mathrm{C}\left(\mathrm{CH}_{3}\right)_{3}\right], 38.2\left(\mathrm{CH}_{2}\right), 38.5\left(\mathrm{CH}_{2}\right)(\mathrm{C} 6, \mathrm{C} 12), 39.51\left(\mathrm{CH}, \mathrm{d}, J_{C-F}=13.3 \mathrm{~Hz}\right), 39.59$ $\left(\mathrm{CH}, \mathrm{d}, J_{C-F}=13.3 \mathrm{~Hz}\right)(\mathrm{C} 5, \mathrm{C} 11), 39.55\left(\mathrm{CH}_{2}, \mathrm{~d}, J_{C-F}=21.3 \mathrm{~Hz}\right), 39.8\left(\mathrm{CH}_{2}, \mathrm{~d}, J_{C-F}=\right.$ $20.7 \mathrm{~Hz})(\mathrm{C} 10, \mathrm{C} 13), 46.1\left(\mathrm{CH}_{2}, \mathrm{~d}, J_{C-F}=18.2 \mathrm{~Hz}, \mathrm{C} 8\right), 56.3\left(\mathrm{C}, \mathrm{d}, J_{C-F}=11.3 \mathrm{~Hz}, \mathrm{C} 7\right)$, $79.8\left(\mathrm{C}, \mathrm{C}\left(\mathrm{CH}_{3}\right)_{3}\right], 93.6\left(\mathrm{C}, \mathrm{d}, J_{C-F}=178.5 \mathrm{~Hz}, \mathrm{C} 9\right), 122.3(\mathrm{CH}), 123.3(\mathrm{CH})(\mathrm{C} 1, \mathrm{C} 4)$, 129.4 (CH, C3), 146.3 (C), 146.9 (C) (C4a, C11a), 152.4 (C, C2), 154.1 (C, NHCOO); HRMS (ESI), calcd for $\left[\mathrm{C}_{20} \mathrm{H}_{25} \mathrm{FN}_{2} \mathrm{O}_{4}-\mathrm{H}^{-}\right] 375.1726$, found 375.1738 .

\subsubsection{0. tert-Butyl (2-amino-9-fluoro-7H-5,6,8,9,10,11-hexahydro-5,9:7,11-} dimethanobenzo[9]annulen-7-yl)carbamate (16)

A suspension of the nitro derivative $15(583 \mathrm{mg}, 1.54 \mathrm{mmol})$ and $\mathrm{PtO}_{2}(48 \mathrm{mg}, 0.12$ $\mathrm{mmol})$ in $\mathrm{EtOH}(100 \mathrm{~mL})$ was hydrogenated at $1 \mathrm{~atm}$ of $\mathrm{H}_{2}$ at room temperature for $4 \mathrm{~h}$. The resulting black suspension was filtered and the filtrate was evaporated at reduced 
pressure to give amine $\mathbf{1 6}$ (495 $\mathrm{mg}, 92 \%$ yield) as a yellow solid: $\mathrm{mp} 118-120{ }^{\circ} \mathrm{C}$; IR $(\mathrm{NaCl})$ v 3411, $3363\left(\mathrm{~N}-\mathrm{H}\right.$ st), 1713 (C=O st), 1616, 1586, $1505\left(\mathrm{NO}_{2} \mathrm{st}\right.$ as), 1453, 1391, 1365, 1340, 1306, $1282\left(\mathrm{NO}_{2} \mathrm{st} \mathrm{s}\right) \mathrm{cm}^{-1} ;{ }^{1} \mathrm{H} \mathrm{NMR}\left(400 \mathrm{MHz}, \mathrm{CDCl}_{3}\right) \delta 1.42[\mathrm{~s}$, $\left.9 \mathrm{H}, \mathrm{C}\left(\mathrm{CH}_{3}\right)_{3}\right], 1.83-2.20(\mathrm{~m}, 10 \mathrm{H}$, methylene protons), $3.06(\mathrm{~m}, 1 \mathrm{H}), 3.11(\mathrm{~m}, 1 \mathrm{H})(5-$ H, 11-H), 3.24 (br.s., 1H), 3.90 (br.s., 1H) (2- $\mathrm{NH}_{2}$ ), 4.51 (br.s., 1H, NHCOO), 6.427 $\left(\mathrm{dd}, J=6.4 \mathrm{~Hz}, J^{\prime}=2.4 \mathrm{~Hz}, 1 \mathrm{H}, 3-\mathrm{H}\right), 6.434(\mathrm{~d}, J=2.4 \mathrm{~Hz}, 1 \mathrm{H}, 1-\mathrm{H}), 6.85(\mathrm{~d}, J=6.4$ $\mathrm{Hz}, 1 \mathrm{H}, 4-\mathrm{H}) ;{ }^{13} \mathrm{C} \mathrm{NMR}\left(100.6 \mathrm{MHz}, \mathrm{CDCl}_{3}\right) \delta 28.6\left[\mathrm{CH}_{3}, \mathrm{C}\left(\mathrm{CH}_{3}\right)_{3}\right], 38.7\left(\mathrm{CH}, \mathrm{d}, J_{C-F}\right.$ $=13.3 \mathrm{~Hz}, \mathrm{C} 5), 38.9\left(\mathrm{CH}_{2}\right), 39.6\left(\mathrm{CH}_{2}\right)(\mathrm{C} 6, \mathrm{C} 12), 39.8\left(\mathrm{CH}, \mathrm{d}, J_{C-F}=13.5 \mathrm{~Hz}, \mathrm{C} 11\right)$, $40.2\left(\mathrm{CH}_{2}, \mathrm{~d}, J_{C-F}=20.1 \mathrm{~Hz}\right), 40.7\left(\mathrm{CH}_{2}, \mathrm{~d}, J_{C-F}=19.5 \mathrm{~Hz}\right)(\mathrm{C} 10, \mathrm{C} 13), 46.4\left(\mathrm{CH}_{2}, \mathrm{~d}\right.$, $\left.J_{C-F}=17.1 \mathrm{~Hz}, \mathrm{C} 8\right), 56.6\left(\mathrm{C}, \mathrm{d}, J_{C-F}=11.5 \mathrm{~Hz}, \mathrm{C} 7\right), 79.4\left[\mathrm{C}, C\left(\mathrm{CH}_{3}\right)_{3}\right], 94.6\left(\mathrm{C}, \mathrm{d}, J_{C-F}\right.$ $=177.0 \mathrm{~Hz}, \mathrm{C} 9), 113.1(\mathrm{CH}), 115.3(\mathrm{CH}(\mathrm{C} 1, \mathrm{C} 3), 129.3(\mathrm{CH}, \mathrm{C} 4), 135.2(\mathrm{C}, \mathrm{C} 2)$, 145.1 (C), 145.9 (C) (C4a, C11a), 154.1 (C, NHCOO); HRMS (ESI), calcd for $\left[\mathrm{C}_{20} \mathrm{H}_{27} \mathrm{FN}_{2} \mathrm{O}_{2}+\mathrm{H}^{+}\right]$347.2129, found 347.2132.

\subsubsection{N-(7-Amino-9-fluoro-7H-5,6,8,9,10,11-hexahydro-5,9:7,11-}

dimethanobenzo[9]annulen-2-yl)-4-[(6-chloro-1,2,3,4-tetrahydroacridin-9yl)amino]butanamide (18a)

$N$ - $\{7$-[(tert-Butoxycarbonyl)amino]-9-fluoro-7H-5,6,8,9,10,11-hexahydro-5,9:7,11dimethanobenzo[9] annulen-2-yl\}-4-[(6-chloro-1,2,3,4-tetrahydroacridin-9yl)amino]butanamide (17a) was prepared as described for 12a. From nitrile 11a (369 $\mathrm{mg}, 1.23 \mathrm{mmol})$, crude carboxylic acid $(2.55 \mathrm{~g})$ was obtained as the hydrochloride salt and used in the following step without further purification. From this crude carboxylic acid and amine 16 (302 mg, $0.87 \mathrm{mmol})$, a brown sticky solid residue (3.11 g) was obtained and subjected to column chromatography purification $(35-70 \mu \mathrm{m}$ silica gel, hexane / EtOAc / Et $3 \mathrm{~N}$ mixtures, gradient elution). On elution with hexane / EtOAc / $\mathrm{Et}_{3} \mathrm{~N}$ 20:80:0.2 to 10:90.5:0.2, impure amide 17a $(235 \mathrm{mg})$ was isolated as a yellow oil and used in the following step without further purification; $R_{f} 0.72\left(\mathrm{CH}_{2} \mathrm{Cl}_{2} / \mathrm{MeOH} /\right.$ 50\% aq. $\mathrm{NH}_{4} \mathrm{OH}$ 95:5:1); LRMS (ESI), $647.3159\left(\mathrm{M}+\mathrm{H}^{+}\right)$.

A mixture of $N$-Boc-protected amide 17a $(218 \mathrm{mg}$ ) and $\mathrm{HCl} /$ dioxane (4N solution, 2.4 $\mathrm{mL}, 9.61 \mathrm{mmol}$ ) was stirred at room temperature for $18 \mathrm{~h}$. The resulting mixture was evaporated under reduced pressure, to give a brown solid which was taken up in water $(3 \mathrm{~mL})$, alkalinized with $10 \%$ aq. $\mathrm{Na}_{2} \mathrm{CO}_{3}(15 \mathrm{~mL})$, and extracted with a mixture $\mathrm{MeOH}$ $/ \mathrm{CHCl}_{3}$ 1:9 $(4 \times 10 \mathrm{~mL})$. The combined organic extracts were dried over anhydrous $\mathrm{Na}_{2} \mathrm{SO}_{4}$ and concentrated in vacuo, to give a light brown oily residue $(213 \mathrm{mg})$, which 
was subjected to column chromatography purification (35-70 $\mu \mathrm{m}$ silica gel, $\mathrm{CH}_{2} \mathrm{Cl}_{2}$ / $\mathrm{MeOH} / 50 \%$ aq. $\mathrm{NH}_{4} \mathrm{OH}$ mixtures, gradient elution). On elution with $\mathrm{CH}_{2} \mathrm{Cl}_{2} / \mathrm{MeOH} /$ 50\% aq. $\mathrm{NH}_{4} \mathrm{OH}$ 98.5:1.5:0.4 to 95:5:0.4, amine 18a (91 mg, 19\% overall yield from amine 16) was isolated as a white solid; $R_{f} 0.22\left(\mathrm{CH}_{2} \mathrm{Cl}_{2} / \mathrm{MeOH} / 50 \%\right.$ aq. $\mathrm{NH} 4 \mathrm{OH}$ 95:5:1).

A solution of $18 \mathrm{a}(50 \mathrm{mg}, 0.09 \mathrm{mmol})$ in $\mathrm{CH}_{2} \mathrm{Cl}_{2}(2 \mathrm{~mL})$ was filtered through a $0.2 \mu \mathrm{m}$ PTFE filter, treated with a methanolic solution of $\mathrm{HCl}(3 \mathrm{~N}$ solution, $0.3 \mathrm{~mL})$, and evaporated at reduced pressure. The solid was washed with pentane $(3 \times 2 \mathrm{~mL})$, to give, after drying at $65^{\circ} \mathrm{C} / 2$ Torr for $48 \mathrm{~h}$, the analytical sample of $\mathbf{1 8 a} \cdot 2 \mathrm{HCl}(49 \mathrm{mg})$, as a white solid: ${ }^{1} \mathrm{H}$ NMR (400 MHz, CD $\left.{ }_{3} \mathrm{OD}\right) \delta 1.80-1.96$ (m, 8H, 2'- $\mathrm{H}_{2}, 3^{\prime}-\mathrm{H}_{2}, 6$ '”- $\mathrm{H}_{\mathrm{A}}$,

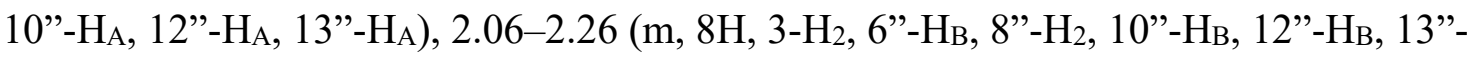
$\left.\mathrm{H}_{\mathrm{B}}\right), 2.58\left(\mathrm{t}, J=6.4 \mathrm{~Hz}, 2 \mathrm{H}, 2-\mathrm{H}_{2}\right), 2.69$ (t, $J=5.6 \mathrm{~Hz}, 2 \mathrm{H}, 1$ ' $\left.-\mathrm{H}_{2}\right), 2.94$ (t, $J=6.0 \mathrm{~Hz}$, 2H, 4'-H2), 3.32 (m, 1H, 11'-H), 3.38 (m, 1H, 5”-H), 4.07 (t, J=6.8 Hz, 2H, 4-H2), 4.85 (s, $\left.{ }^{+} \mathrm{NH}, \mathrm{NH}\right), 7.10$ (d, J=8.4 Hz, 1H, 4’'-H), 7.27 (dd, $J=8.4 \mathrm{~Hz}, J^{\prime}=2.4 \mathrm{~Hz}, 1 \mathrm{H}$, 3"'-H), 7.36 (d, $J=2.4 \mathrm{~Hz}, 1 \mathrm{H}, 1$ '-H), 7.52 (dd, $J=9.2 \mathrm{~Hz}, J^{\prime}=2.4 \mathrm{~Hz}, 1 \mathrm{H}, 7$ '-H), 7.76 $\left(\mathrm{d}, J=2.4 \mathrm{~Hz}, 1 \mathrm{H}, 5^{\prime}-\mathrm{H}\right), 8.46$ (d, $\left.J=9.2 \mathrm{~Hz}, 1 \mathrm{H}, 8^{\prime}-\mathrm{H}\right) ;{ }^{13} \mathrm{C} \mathrm{NMR}(100.6 \mathrm{MHz}$, $\left.\mathrm{CD}_{3} \mathrm{OD}\right) \delta 21.7\left(\mathrm{CH}_{2}, \mathrm{C} 3{ }^{\prime}\right), 22.8\left(\mathrm{CH}_{2}, \mathrm{C} 2{ }^{\prime}\right), 24.8\left(\mathrm{CH}_{2}, \mathrm{C}^{\prime}{ }^{\prime}\right), 26.5\left(\mathrm{CH}_{2}, \mathrm{C} 3\right), 29.3$ $\left(\mathrm{CH}_{2}, \mathrm{C}^{\prime}\right.$ '), $35.1\left(\mathrm{CH}_{2}, \mathrm{C} 2\right), 38.6\left(\mathrm{CH}_{2}\right), 38.8\left(\mathrm{CH}_{2}\right)\left(\mathrm{C} 6 ”, \mathrm{C} 12\right.$ ”), $39.5\left(\mathrm{CH}, \mathrm{d}, J_{C-F}=\right.$ $13.5 \mathrm{~Hz}, \mathrm{C} 5 ”), 40.4$ (CH, d, $J_{C-F}=12.9 \mathrm{~Hz}, \mathrm{C} 11$ ”), 40.7(CH $2, \mathrm{~d}, J_{C-F}=19.4 \mathrm{~Hz}, \mathrm{C} 10 ”$, C13”), $45.9\left(\mathrm{CH}_{2}, \mathrm{~d}, J_{C-F}=20.7 \mathrm{~Hz}, \mathrm{C} 8\right.$ "), $49.1\left(\mathrm{CH}_{2}, \mathrm{C} 4\right), 58.1\left(\mathrm{C}, \mathrm{d}, J_{C-F}=10.3 \mathrm{~Hz}\right.$, C7”), 94.0 (C, d, $J_{C-F}=179.3$ Hz, C9”), 113.4 (C, C9a'), 115.4 (C, C8a'), 119.0 (CH, C5'), 119.6 (CH, C3”), 120.9 (CH, C1”), 126.7 (CH, C7'), 129.0 (CH, C8'), 130.0 (CH, C4”), 138.9 (C, C2”), 140.0 (C, C6'), 140.5 (C, C10a'), 141.0 (C, C4a”), 145.8 (C, C11a”), 151.9 (C, C4a'), 157.9 (C, C9’), 173.5 (C, C1); HRMS (ESI), calcd for $\left[\mathrm{C}_{32} \mathrm{H}_{36}{ }^{35} \mathrm{ClFN}_{4} \mathrm{O}+\mathrm{H}^{+}\right]$547.2634, found 547.2632.

\subsubsection{N-(7-Amino-9-fluoro-7H-5,6,8,9,10,11-hexahydro-5,9:7,11-}

dimethanobenzo[9]annulen-2-yl)-5-[(6-chloro-1,2,3,4-tetrahydroacridin-9yl)amino]pentanamide (18b)

This compound was prepared as described for 17a. From nitrile $11 \mathbf{b}(1.10 \mathrm{~g}, 3.51$ mmol), crude carboxylic acid (5.80 g) was obtained as the hydrochloride salt and used in the following step without further purification. From this crude carboxylic acid and amine 16 (575 mg, $1.66 \mathrm{mmol}$ ), a brown sticky solid residue (9.84 g) was obtained and subjected to column chromatography purification $(35-70 \mu \mathrm{m}$ silica gel, hexane / EtOAc 
/ $\mathrm{Et}_{3} \mathrm{~N}$ mixtures, gradient elution). On elution with hexane / EtOAc / $\mathrm{Et}_{3} \mathrm{~N}$ 10:90:0.2 to 0:100:0.2, impure $N$-\{7-[(tert-butoxycarbonyl)amino]-9-fluoro-7H-5,6,8,9,10,11hexahydro-5,9:7,11-dimethanobenzo[9] annulen-2-yl\}-5-[(6-chloro-1,2,3,4tetrahydroacridin-9-yl)amino]pentanamide $(\mathbf{1 7 b}, 312 \mathrm{mg})$ was isolated as a brown oil and used in the following step without further purification; $R_{f} 0.72\left(\mathrm{CH}_{2} \mathrm{Cl}_{2} / \mathrm{MeOH} /\right.$ 50\% aq. $\mathrm{NH}_{4} \mathrm{OH}$ 95:5:1); LRMS (ESI), $661.3323\left(\mathrm{M}+\mathrm{H}^{+}\right)$.

From $\mathrm{N}$-Boc-protected amide $\mathbf{1 7 b}(303 \mathrm{mg})$ and $\mathrm{HCl} /$ dioxane (4N solution, $3.3 \mathrm{~mL}$, $13.0 \mathrm{mmol})$, a light brown oily residue (261 $\mathrm{mg}$ ) was obtained and subjected to column chromatography purification (35-70 $\mu$ m silica gel, $\mathrm{CH}_{2} \mathrm{Cl}_{2} / \mathrm{MeOH} / 50 \%$ aq. $\mathrm{NH}+\mathrm{OH}$ mixtures, gradient elution). On elution with $\mathrm{CH}_{2} \mathrm{Cl}_{2} / \mathrm{MeOH} / 50 \%$ aq. $\mathrm{NH}_{4} \mathrm{OH}$ 98:2:0.4, amine 18b (94 mg, 10\% overall yield from amine 16) was isolated as a white solid; $R_{f} 0.45\left(\mathrm{CH}_{2} \mathrm{Cl}_{2} / \mathrm{MeOH} / 50 \%\right.$ aq. $\mathrm{NH}_{4} \mathrm{OH}$ 95:5:1).

A solution of $\mathbf{1 8 b}(19 \mathrm{mg}, 0.03 \mathrm{mmol})$ in $\mathrm{CH}_{2} \mathrm{Cl}_{2}(1 \mathrm{~mL})$ was filtered through a $0.2 \mu \mathrm{m}$ PTFE filter, treated with a methanolic solution of $\mathrm{HCl}(3 \mathrm{~N}$ solution, $0.03 \mathrm{~mL})$, and evaporated at reduced pressure. The solid was washed with pentane $(3 \times 2 \mathrm{~mL})$, to give, after drying at $65^{\circ} \mathrm{C} / 2$ Torr for $48 \mathrm{~h}$, the analytical sample of $\mathbf{1 8 b} \cdot 2 \mathrm{HCl}(22 \mathrm{mg})$, as a yellow solid: ' $\mathrm{H}$ NMR (400 MHz, $\left.\mathrm{CD}_{3} \mathrm{OD}\right) \delta$ 1.78-2.00 (m, 12H, 3- $\mathrm{H}_{2}, 4-\mathrm{H}_{2}, 2$ '- $-\mathrm{H}_{2}, 3^{\prime}$ -

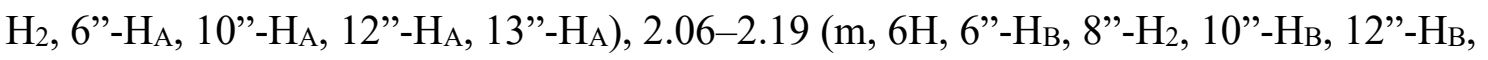
13 '- $\left.-\mathrm{H}_{\mathrm{B}}\right), 2.45$ (t, $\left.J=7.2 \mathrm{~Hz}, 2 \mathrm{H}, 2-\mathrm{H}_{2}\right), 2.70$ (t, $\left.J=5.2 \mathrm{~Hz}, 2 \mathrm{H}, 1^{\prime}-\mathrm{H}_{2}\right), 2.99$ (t, $J=5.2$ $\left.\mathrm{Hz}, 2 \mathrm{H}, 4^{\prime}-\mathrm{H}_{2}\right), 3.29-3.34$ (m, 1H, 11'-H), 3.38 (m, 1H, 5”-H), 3.99 (t, $J=6.8 \mathrm{~Hz}, 2 \mathrm{H}$, 5- $\left.\mathrm{H}_{2}\right), 4.85\left(\mathrm{~s},{ }^{+} \mathrm{NH}, \mathrm{NH}\right), 7.10$ (d, $\left.J=8.4 \mathrm{~Hz}, 1 \mathrm{H}, 4{ }^{\prime \prime}-\mathrm{H}\right), 7.29$ (dd, $J=8.4 \mathrm{~Hz}, J^{\prime}=2.0$ Hz, 1H, 3'-H), 7.38 (d, J=2.0 Hz, 1H, 1'-H), 7.53 (dd, J=9.2 Hz, J'= 2.0 Hz, 1H, 7'H), $7.76\left(\mathrm{~d}, J=2.0 \mathrm{~Hz}, 1 \mathrm{H}, 5^{\prime}-\mathrm{H}\right), 8.40$ (d, $\left.J=9.2 \mathrm{~Hz}, 1 \mathrm{H}, 8^{\prime}-\mathrm{H}\right) ;{ }^{13} \mathrm{C}$ NMR (100.6 $\left.\mathrm{MHz}, \mathrm{CD}_{3} \mathrm{OD}\right) \delta 21.8\left(\mathrm{CH}_{2}, \mathrm{C}^{\prime}\right.$ '), $22.9\left(\mathrm{CH}_{2}, \mathrm{C} 2\right.$ '), $23.5\left(\mathrm{CH}_{2}, \mathrm{C} 3\right), 24.8\left(\mathrm{CH}_{2}, \mathrm{C}^{\prime}\right.$ '), $29.4\left(\mathrm{CH}_{2}, \mathrm{C} 4\right.$ '), $30.7\left(\mathrm{CH}_{2}, \mathrm{C} 4\right), 36.9\left(\mathrm{CH}_{2}, \mathrm{C} 2\right), 38.6\left(\mathrm{CH}_{2}\right), 38.8\left(\mathrm{CH}_{2}\right)\left(\mathrm{C}^{\prime \prime}, \mathrm{C} 12\right.$ '), $39.5\left(\mathrm{CH}, \mathrm{d}, J_{C-F}=13.0 \mathrm{~Hz}, \mathrm{C} 5\right.$ ”), $40.4\left(\mathrm{CH}, \mathrm{d}, J_{C-F}=13.1 \mathrm{~Hz}, \mathrm{C} 11\right.$ ”), $40.7\left(\mathrm{CH}_{2}, \mathrm{~d}, J_{C-F}\right.$ $=19.9 \mathrm{~Hz}, \mathrm{C} 10$ ", C13”), $45.9\left(\mathrm{CH}_{2}, \mathrm{~d}, J_{C-F}=20.6 \mathrm{~Hz}, \mathrm{C} 8\right.$ ”), $49.3\left(\mathrm{CH}_{2}, \mathrm{C} 5\right), 58.1$ (C, d, $\left.J_{C-F}=10.7 \mathrm{~Hz}, \mathrm{C} 7 ”\right), 94.0$ (C, d, $J_{C-F}=180.2 \mathrm{~Hz}, \mathrm{C9}$ '), 113.5 (C, C9a'), 115.5 (C, C8a'), 119.1 (CH, C5'), 119.7 (CH, C3”), 121.0 (CH, C1”), 126.8 (CH, C7'), 128.8 (CH, C8'), 129.9 (CH, C4”), 138.9 (C, C2”), 140.0 (C, C6'), 140.5 (C, C10a'), 141.0 (C, C4a”), 145.7 (C, C11a”), 152.1 (C, C4a'), 157.9 (C, C9'), 174.0 (C, C1); HRMS (ESI), calcd for $\left[\mathrm{C}_{33} \mathrm{H}_{38}{ }^{35} \mathrm{ClFN}_{4} \mathrm{O}+\mathrm{H}^{+}\right]$561.2791, found 561.2796.

\subsection{Biological assays}




\subsubsection{Evaluation of $h A C h E$ and $h B C h E$ inhibitory activities}

The inhibitory activity of the target compounds towards human recombinant $\mathrm{AChE}$ and human serum BChE (Sigma, Milan, Italy) was evaluated spectrophotometrically following the method of Ellman et al. [61]. The enzyme stock solutions were prepared by dissolving human recombinant $\mathrm{AChE}$ or human serum $\mathrm{BChE}$ lyophilized powders in $0.1 \%$ Triton $\mathrm{X}-100 / 0.1 \mathrm{M}$ potassium phosphate, $\mathrm{pH} 8.0$, or in $0.1 \%$ aq. gelatin, respectively. The stock solutions of the target compounds $(1 \mathrm{mM})$ were prepared in $\mathrm{MeOH}$. The assay solution consisted of $340 \mu \mathrm{M}$ 5,5'-dithiobis(2-nitrobenzoic acid) (DTNB), $0.02 \mathrm{unit} / \mathrm{mL} \mathrm{hAChE}$ or hBChE, and $550 \mu \mathrm{M}$ acetylthiocholine iodide or butyrylthiocholine iodide, for $\mathrm{AChE}$ and $\mathrm{BChE}$, respectively, in $0.1 \mathrm{M}$ potassium phosphate, $\mathrm{pH}$ 8.0. Assay solutions with and without the target compounds were preincubated at $37^{\circ} \mathrm{C}$ for $20 \mathrm{~min}$, before the addition of the substrate (acetylthiocholine iodide or butyrylthiocholine iodide). Blank solutions containing all components except the enzymes were prepared in parallel to correct for non-enzymatic hydrolysis of the substrates. Initial rate assays were performed at $37^{\circ} \mathrm{C}$ with a Jasco V-530 double beam spectrophotometer. At least five increasing concentrations of the target compounds, which led to $20-80 \%$ inhibition of the enzymatic activities, were assayed. IC 50 values were calculated using Microcal Origin 3.5 software (Microcal Software, Inc).

\subsubsection{Evaluation of NMDA receptor antagonist activity}

The functional assay for the determination of the antagonistic activity of the target compounds at the NMDA receptors was performed using primary cultures of rat cerebellar granule neurons, which were prepared following established protocols [49]. Cells were grown on $10 \mathrm{~mm}$ poly-L-lysine coated glass cover slips and used for the experiments after 6-9 days in vitro. Cells were loaded with $6 \mu \mathrm{M}$ Fura-2 AM (ThermoFisher-Invitrogen) for $30 \mathrm{~min}$, and then, the coverslip was mounted on a quartz cuvette containing a $\mathrm{Mg}^{2+}$-free Locke-Hepes (LH) buffer using a special holder. Measurements were performed using a Perkin Elmer LS-55 fluorescence spectrometer equipped with a fast-filter accessory, under mild agitation at $37{ }^{\circ} \mathrm{C}$. Analysis from each sample was recorded real-time during $1400 \mathrm{~s}$. After stimulation with NMDA (100 $\mu \mathrm{M}$, in the presence of $10 \mu \mathrm{M}$ glycine), increasing cumulative concentrations of the target compounds were added (range: $0.1-100 \mu \mathrm{M}$ ). To avoid precipitation, the tested compounds were dissolved in LH buffer containing a final concentration of $1.8 \% \beta$ cyclodextrin. The percentages of inhibition at every tested concentration were analyzed 
using a non-linear regression curve fitting (variable slope) by using the software GraphPad Prism 5.0.

\subsubsection{Evaluation of BACE-1 inhibitory activity}

The inhibitory activity of the target compounds towards human recombinant BACE-1 ( $\beta$-secretase, Invitrogen) was evaluated by employing the Panvera peptide as substrate [71]. Ten $\mu \mathrm{L}$ of substrate ( $250 \mathrm{nM}$ final concentration) were added to $10 \mu \mathrm{L}$ of solution of the target compounds or buffer in control wells ( $20 \mathrm{mM}$ sodium acetate, $\mathrm{pH} 4.5$, containing CHAPS $0.1 \% \mathrm{w} / \mathrm{v})$. To start the reaction $10 \mu \mathrm{L}$ of BACE-1 enzyme were added $(12.91 \mathrm{mU})$. The enzyme was left to react for $1 \mathrm{~h}$ at $37^{\circ} \mathrm{C}$. The fluorescence signal was read at $\lambda \mathrm{em}=544 \mathrm{~nm}(\lambda \mathrm{ex}=590 \mathrm{~nm})$ after adding $10 \mu \mathrm{L}$ of STOP solution (2.5M NaOAc). The DMSO concentration in the final mixture was maintained below $5 \%(\mathrm{v} / \mathrm{v})$ to guarantee no significant loss of enzyme activity. The fluorescence intensities with and without inhibitor were compared and the percent of inhibition due to the presence of the target compounds was calculated. The background signal was measured in control wells containing all the reagents, except BACE-1, and was subtracted. The $\%$ of inhibition due to the presence of test compounds was calculated by the following expression: $100-\left(\mathrm{IF}_{\mathrm{i}} / \mathrm{IF}_{\mathrm{o}} \times 100\right)$, where $\mathrm{IF}_{\mathrm{i}}$ and $\mathrm{IF}_{\mathrm{o}}$ are the fluorescence intensities obtained for BACE-1 in the presence and in the absence of inhibitor, respectively.

\subsubsection{Evaluation of $A \beta 42$ and tau anti-aggregating activities}

The inhibitory activities of the target compounds towards $A \beta 42$ and tau aggregation were assessed using intact $E$. coli cells, as previously described [51,65,66]. E. coli BL21 (DE3) competent cells were transformed with the pET28a vector (Novagen, Inc., Madison, WI, USA), which carryies the DNA sequence of A $\beta 42$, or with pTARA, which contains the RNA-polymerase gen of T7 phage (T7RP) under the control of the promoter PBAD, and were then transformed with the pRKT42 vector, encoding four repeats of tau protein in two inserts. Ten $\mathrm{mL}$ of $\mathrm{M} 9$ minimal medium containing 50 $\mu \mathrm{g} / \mathrm{mL}$ of kanamycin (for $\mathrm{A} \beta 42$ overexpression) or $0.5 \%$ of glucose, $50 \mu \mathrm{g} / \mathrm{mL}$ of ampicillin and $12.5 \mu \mathrm{g} / \mathrm{mL}$ of chloramphenicol (for tau overexpression) were inoculated with a colony of BL21 (DE3) cells bearing the plasmids. The volume of overnight culture necessary to get a 1:500 dilution was added into fresh M9 minimal medium 
containing $50 \mu \mathrm{g} / \mathrm{mL}$ of kanamycin and $250 \mu \mathrm{M}$ of Th-S (for A $\beta 42$ overexpression) or $0.5 \%$ of glucose, $50 \mu \mathrm{g} / \mathrm{mL}$ of ampicillin, $12.5 \mu \mathrm{g} / \mathrm{mL}$ of chloramphenicol, and $250 \mu \mathrm{M}$ of Th-S (for tau overexpression). The cultures were grown overnight at $37{ }^{\circ} \mathrm{C}$ and 250 rpm until cell density reached $\mathrm{OD}_{600}=0.6$. A volume of $980 \mu \mathrm{L}$ of the cultures was transferred into $1.5 \mathrm{~mL}$ eppendorf tubes that contained $10 \mu \mathrm{L}$ of a solution of the target compound in DMSO and $10 \mu \mathrm{L}$ of isopropyl 1-thio- $\beta$-D-galactopyranoside (IPTG) at $100 \mathrm{mM}$ (for $\mathrm{A} \beta 42$ overexpression) or $10 \mu \mathrm{L}$ of arabinose at $25 \%$ (for tau overexpression), thereby leading to a final inhibitor concentration of $10 \mu \mathrm{M}$. The resulting cultures were grown overnight at $37^{\circ} \mathrm{C}$ and $1400 \mathrm{rpm}$ with a Thermomixer (Eppendorf, Hamburg, Germany). The same amount of DMSO without the target compound was added to the sample as a negative control (maximal amount of A $\beta 42$ or tau), whereas non-induced samples (in the absence of IPTG or arabinose) were prepared as positive controls (absence of $\mathrm{A} \beta 42$ or tau), and to assess the potential intrinsic toxicity of the target compounds.

The effects of the target compounds on $A \beta 42$ or tau aggregation were assessed using a previously described fluorescence assay $[51,65,66]$, by employing a $2500 \mathrm{mM}$ stock solution of thioflavin-S (Th-S, T1892, Sigma, St. Louis, MO, USA) in double-distilled water (Milli-Q system, Millipore, USA), and measuring the Th-S spectra on an Aminco Bowman Series 2 luminescence spectrophotometer (Aminco-Bowman AB2, SLM Aminco, Rochester, NY, USA) in the range $460-600 \mathrm{~nm}$ at $25{ }^{\circ} \mathrm{C}$, with an excitation wavelength of $440 \mathrm{~nm}$ and slit widths of $4 \mathrm{~nm}$, and an emission wavelength of $485 \mathrm{nM}$.

\subsubsection{Evaluation of brain permeability: PAMPA-BBB assay}

The brain permeability $\left(P_{\mathrm{e}}\right)$ of the target compounds was determined by the in vitro parallel artificial membrane permeability assay for blood-brain barrier penetration of Di et al. [70], which employs a lipid extract of porcine brain membrane in $\mathrm{PBS} / \mathrm{EtOH}$ 70:30. The assay was validated by comparison of the experimental and reported $P_{\mathrm{e}}$ values of a set of fourteen commercial drugs (Table 2), and the following correlation was obtained: $P_{\mathrm{e}}(\exp )=1.5758 P_{\mathrm{e}}(\mathrm{lit})-1.1459\left(\mathrm{R}^{2}=0.9241\right)$. From this equation and the limits established by Di et al. for BBB permeation, the threshold for high BBB permeation $(\mathrm{CNS}+)$ was set at $P e\left(10^{-6} \mathrm{~cm} / \mathrm{s}\right)>5.16$; whereas the range for low $\mathrm{BBB}$ permeation $(\mathrm{CNS}-)$ was set at $P e\left(10^{-6} \mathrm{~cm} / \mathrm{s}\right)<2.01$, and that for uncertain BBB permeation $(\mathrm{CNS} \pm)$ at $5.16>P e\left(10^{-6} \mathrm{~cm} / \mathrm{s}\right)>2.01$. 


\section{Table 2}

Experimental and reported BBB permeability values $\left(P e 10^{-6} \mathrm{~cm} / \mathrm{s}\right)$ of the commercial drugs used for assay validation.

\begin{tabular}{|c|c|c|}
\hline Drug & Reported $P e^{a}$ & Experimental $P e^{b}$ \\
\hline Cimetidine & 0.0 & $0.7 \pm 0.1$ \\
\hline Lomefloxacin & 1.1 & $0.8 \pm 0.1$ \\
\hline Norfloxazin & 0.1 & $0.9 \pm 0.1$ \\
\hline Ofloxazin & 0.8 & $1.0 \pm 0.1$ \\
\hline Hydrocortisone & 1.9 & $1.4 \pm 0.1$ \\
\hline Piroxicam & 2.5 & $2.1 \pm 0.1$ \\
\hline Clonidine & 5.3 & $6.5 \pm 0.1$ \\
\hline Corticosterone & 5.1 & $6.7 \pm 0.1$ \\
\hline Imipramine & 13.0 & $12.3 \pm 0.1$ \\
\hline Promazine & 8.8 & $13.8 \pm 0.3$ \\
\hline Progesterone & 9.3 & $16.8 \pm 0.3$ \\
\hline Desipramine & 12.0 & $17.8 \pm 0.1$ \\
\hline Testosterone & 17.0 & $26.4 \pm 0.3$ \\
\hline Verapamil & 16.0 & $28.6 \pm 0.3$ \\
\hline
\end{tabular}

\section{Conflicts of interest}

There are no conflicts to declare.

\section{Acknowledgments}


This work was supported by Ministerio de Ciencia, Innovación y Universidades, Agencia Estatal de Investigación (AEI) and FEDER (SAF2017-82771-R) and Generalitat de Catalunya (GC) (2017SGR106). Fellowships from GC to F.J.P.-A., from Ministerio de Educación, Cultura y Deporte to C.P. and A.L.T., and from Lifelong Learning Programme / Erasmus to D.P., and a contract from the Juan de la Cierva program of Ministerio de Economía y Competitividad to A.E. (grant JCI-2012-12193) are gratefully acknowledged.

\section{Appendix A. Supplementary material}

Supplementary data to this article can be found online at http://dx.doi.org/. These data include copies of the ${ }^{1} \mathrm{H}$ and ${ }^{13} \mathrm{C}$ NMR spectra of the tested compounds.

\section{References}

[1] M. Prince, A. Wimo, M. Guerchet, G.-C. Ali, Y.-T. Wu, M. Prina, World Alzheimer Report 2015. The global impact of dementia. An analysis of prevalence, incidence, cost \& trends; Alzheimer's Disease International: London, 2015; http://www.alz.co.uk.

[2] S.H. Kim, N. Kandiah, J.-L. Hsu, C. Suthisisang, C. Udommongkol, A. Dash, Beyond symptomatic effects: potential of donepezil as a neuroprotective agent and disease modifier in Alzheimer's disease, Br. J. Pharmacol. 174 (2017) 4224-4232.

[3] D. Muñoz-Torrero, Acetylcholinesterase inhibitors as disease-modifying therapies for Alzheimer's disease, Curr. Med. Chem. 15 (2008) 2433-2445.

[4] L.A. Mohamed, H. Qosa, A. Kaddoumi, Age-related decline in brain and hepatic clearance of amyloid-beta is rectified by the cholinesterase inhibitors donepezil and rivastigmine in rats, ACS Chem. Neurosci. 6 (2015) 725-736.

[5] J. Folch, O. Busquets, M. Ettcheto, E. Sánchez-López, R.D. Castro-Torres, E. Verdaguer, M.L. Garcia, J. Olloquequi, G. Casadesús, C. Beas-Zarate, C. Pelegri, J. Vilaplana, C. Auladell, A. Camins, Memantine for the treatment of dementia: A review on its current and future applications, J. Alzheimers Dis. 62 (2018) 1223-1240.

[6] K. Takahashi-Ito, M. Makino, K. Okado, T. Tomita, Memantine inhibits $\beta$ amyloid aggregation and disassembles preformed $\beta$-amyloid aggregates, Biochem. Biophys. Res. Commun. 493 (2017) 158-163. 
[7] S.A. Lipton, Paradigm shift in neuroprotection by NMDA receptor blockade: memantine and beyond, Nat. Rev. Drug Discovery 5 (2006) 160-170.

[8] J.L. Cummings, T. Morstof, K. Zhong, Alzheimer's disease drug-development pipeline: few candidates, frequent failures, Alzheimers Res. Ther. 6 (2014) 37.

[9] S.O. Bachurin, E.V. Bovina, A.A. Ustyugov, Drugs in clinical trials for Alzheimer's disease: The major trends, Med. Res. Rev. 37 (2017) 1186-1225.

[10] C.-X. Gong, F. Liu, K. Iqbal, Multifactorial hypothesis and multi-targets for Alzheimer's disease, J. Alzheimers Dis. 64 (2018) S107-S117.

[11] A. Cavalli, M.L. Bolognesi, A. Minarini, M. Rosini, V. Tumiatti, M. Recanatini, C. Melchiorre, Multi-target-directed ligands to combat neurodegenerative diseases, J. Med. Chem. 51 (2008) 347-372.

[12] R. Morphy, Z. Rankovic, Designing multiple ligands - medicinal chemistry strategies and challenges, Curr. Pharm. Des. 15 (2009) 587-600.

[13] E. Proschak, H. Stark, D. Merk, Polypharmacology by design: A medicinal chemist's perspective on multitargeting compounds, J. Med. Chem. 62 (2019), $420-444$.

[14] M.L. Bolognesi, Polypharmacology in a single drug: Multitarget drugs, Curr. Med. Chem. 20 (2013) 1639-1645.

[15] Y. Yabuki, K. Matsuo, K. Hirano, Y. Shinoda, S. Moriguchi, K. Fukunaga, Combined memantine and donepezil treatment improves behavioral and psychological symptoms of dementia-like behaviors in olfactory bulbectomized mice, Pharmacology 99 (2017) 160-171.

[16] A. Atri, S.B. Hendrix, V. Pejovi, R.K. Hofbauer, J. Edwards, J.L. Molinuevo, S.M. Graham, Cumulative, additive benefits of memantine-donepezil combination over component monotherapies in moderate to severe Alzheimer's dementia: a pooled area under the curve analysis, Alzheimers Res. Ther. 7 (2015) 28.

[17] P.T. Francis, C.G. Parsons, R.W. Jones, Rationale for combining glutamatergic and cholinergic approaches in the symptomatic treatment of Alzheimer's disease, Expert. Rev. Neurother. 12 (2012) 1351-1365.

[18] R.T. Owen, Memantine and donepezil: a fixed drug combination for the treatment of moderate to severe Alzheimer's dementia, Drugs Today 52 (2016) 239-248. 
[19] S.L. Greig, Memantine ER/donepezil: a review in Alzheimer's disease, CNS Drugs 29 (2015) 963-970.

[20] M.G. Savelieff, G. Nam, J. Kang, H.J. Lee, M. Lee, M.H. Lim, Development of multifunctional molecules as potential therapeutic candidates for Alzheimer's disease, Parkinson's disease, and amyotrophic lateral sclerosis in the last decade, Chem. Rev. 119 (2019) 1221-1322.

[21] M. de Freitas Silva, K.S.T. Dias, V.S. Gontijo, C.J.C. Ortiz, C. Viegas, Multitarget directed drugs as a modern approach for drug design towards Alzheimer's disease: an update, Curr. Med. Chem. 25 (2018) 3491-3525.

[22] D. Muñoz-Torrero, Multitarget anti-Alzheimer hybrid compounds: Do they work in vivo?, in Design of Hybrid Molecules for Drug Development, M. Decker (Ed.), 2017, Elsevier, Amsterdam, pp.167-192.

[23] Y. Duarte, A. Fonseca, M. Gutiérrez, F. Adasme-Carreño, C. Muñoz-Gutierrez, J. Alzate-Morales, L. Santana, E. Uriarte, R. Álvarez, M.J. Matos, Novel coumarin-quinoline hybrids: Design of multitarget compounds for Alzheimer's disease, ChemistrySelect 4 (2019) 551-558.

[24] J. Hu, T. Pan, B. An, Z. Li, X. Li, L. Huang, Synthesis and evaluation of clioquinol-rolipram/roflumilast hybrids as multitarget-directed ligands for the treatment of Alzheimer's disease, Eur. J. Med. Chem. 163 (2019) 512-526.

[25] L. Pisani, R.M. Iacobazzi, M. Catto, M. Rullo, R. Farina, N. Denora, S. Cellamare, C.D. Altomare, Investigating alkyl nitrates as nitric oxide releasing precursors of multitarget acetylcholinesterase-monoamine oxidase B inhibitors, Eur. J. Med. Chem. 161 (2019) 292-309.

[26] Z. Wang, J. Hu, X. Yang, X. Feng, X. Li, L. Huang, A.S.C. Chan, Design, synthesis, and evaluation of orally bioavailable quinoline-indole derivatives as innovative multitarget-directed ligands: Promotion of cell proliferation in the adult murine hippocampus for the treatment of Alzheimer's disease, J. Med. Chem. 61 (2018) 1871-1894.

[27] Ó. M. Bautista-Aguilera, J. Budni, F. Mina, E. B. Medeiros, W. DeutherConrad, J. M. Entrena, I. Moraleda, I. Iriepa, F. López-Muñoz, J. MarcoContelles, Contilisant, a tetratarget small molecule for Alzheimer's disease therapy combining cholinesterase, monoamine oxidase inhibition and H3R antagonism with sigma 1R agonism profile, J. Med. Chem 61 (2018) 69376943. 
[28] A. Gandini, M. Bartolini, D. Tedesco, L. Martinez-Gonzalez, C. Roca, N. E. Campillo, J. Zaldivar-Diez, C. Perez, G. Zuccheri, G. Miti, A. Feoli, S. Castellano, S. Petralla, B. Monti, M. Rossi, F. Moda, G. Legname, A. Martinez, M. L. Bolognesi, Tau-centric multitarget approach for Alzheimer's disease: Development of first-in-class dual glycogen synthase kinase $3 \beta$ and tau aggregation inhibitors, J. Med. Chem. 61 (2018) 7640-7656.

[29] J. Lalut, G. Santoni, D. Karila, C. Lecoutey, A. Davis, F. Nachon, I. Silman, J. Sussman, M. Weik, T. Maurice, P. Dallemagne, C. Rochais, Novel multitargetdirected ligands targeting acetylcholinesterase and $\sigma 1$ receptors as lead compounds for treatment of Alzheimer's disease: Synthesis, evaluation, and structural characterization of their complexes with acetylcholinesterase, Eur. J. Med. Chem. 162 (2019) 234-248.

[30] G. Cheng, P. Xu, M. Zhang, J. Chen, R. Sheng, Y. Ma, Resveratrol-maltol hybrids as multi-target-directed agents for Alzheimer's disease, Bioorg. Med. Chem. 26 (2018) 5759-5765.

[31] P. Cai, S.-Q. Fang, H.-L. Yang, X.-L. Yang, Q.-H. Liu, L.-Y. Kong, X.-B. Wang, Donepezil-butylated hydroxytoluene (BHT) hybrids as Anti-Alzheimer's disease agents with cholinergic, antioxidant, and neuroprotective properties, Eur. J. Med. Chem. 157 (2018) 161-176.

[32] M. Chioua, E. Buzzi, I. Moraleda, I. Iriepa, M. Maj, A. Wnorowski, C. Giovannini, A. Tramarin, F. Portali, L. Ismaili, P. López-Alvarado, M.L. Bolognesi, K. Jóźwiak, J.C. Menéndez, J. Marco-Contelles, M. Bartolini, Tacripyrimidines, the first tacrine-dihydropyrimidine hybrids, as multi-targetdirected ligands for Alzheimer's disease, Eur. J. Med. Chem. 155 (2018) 839846.

[33] A. Hiremathad, R.S. Keri, A.R. Esteves, S.M. Cardoso, S. Chaves, M.A. Santos, Novel tacrine-hydroxyphenylbenzimidazole hybrids as potential multitarget drug candidates for Alzheimer's disease, Eur. J. Med. Chem. 148 (2018) 255267.

[34] X.-Y. Jiang, T.-K. Chen, J.-T. Zhou, S.-Y. He, H.-Y. Yang, Y. Chen, W. Qu, F. Feng, H.-P. Sun, Dual GSK-3 $\beta / A C h E$ inhibitors as a new strategy for multitargeting anti-Alzheimer's disease drug discovery, ACS Med. Chem. Lett. 9 (2018) 171-176. 
[35] A. Więckowska, T. Wichur, J. Godyń, A. Bucki, M. Marcinkowska, A. Siwek, K. Więckowski, P. Zaręba, D. Knez, M. Głuch-Lutwin, G. Kazek, G. Latacz, K. Mika, M. Kołaczkowski, J. Korabecny, O. Soukup, M. Benkova, K. KiećKononowicz, S. Gobec, B. Malawska, Novel multitarget-directed ligands aiming at symptoms and causes of Alzheimer's disease, ACS Chem. Neurosci. 9 (2018) 1195-1214.

[36] D. Dolles, M. Hoffmann, S. Gunesch, O. Marinelli, J. Möller, G. Santoni, A. Chatonnet, M.J. Lohse, H.-J. Wittmann, A. Strasser, M. Nabissi, T. Maurice, M. Decker, Structure-activity relationships and computational investigations into the development of potent and balanced dual-acting butyrylcholinesterase inhibitors and human cannabinoid receptor 2 ligands with pro-cognitive in vivo profiles, J. Med. Chem. 61 (2018) 1646-1663.

[37] N. Chufarova, K. Czarnecka, R. Skibiński, M. Cuchra, I. Majsterek, P. Szymański, New tacrine-acridine hybrids as promising multifunctional drugs for potential treatment of Alzheimer's disease, Arch. Phar. 351 (2018) 1800050.

[38] M. Rosini, E. Simoni, M. Bartolini, A. Cavalli, L. Ceccarini, N. Pascu, D.W. McClymont, A. Tarozzi, M.L. Bolognesi, A. Minarini, V. Tumiatti, V. Andrisano, I.R. Mellor, C. Melchiorre, Inhibition of acetylcholinesterase, $\beta$ amyloid aggregation, and NMDA receptors in Alzheimer's disease: A promising direction for the multi-target-directed ligands gold rush, J. Med. Chem. 51 (2008) 4381-4384.

[39] S.O. Bachurin, E.F. Shevtsova, G.F. Makhaeva, V.V. Grigoriev, N.P. Boltneva, N.V. Kovaleva, S.V. Lushchekina, P.N. Shevtsov, M.E. Neganova, O.M. Redkozubova, E.V. Bovina, A.V. Gabrelyan, V.P. Fisenko, V.B. Sokolov, A.Y. Aksinenko, V. Echeverria, G.E. Barreto, G. Aliev, Novel conjugates of aminoadamantanes with carbazole derivatives as potential multitarget agents for AD treatment, Sci. Rep. 7 (2017) 45627.

[40] Y. Rook, K.-U. Schnmidtke, F. Gaube, D. Shepmann, B. Wünsch, J. Heilmann, J. Lehmann, T. Winckler, Bivalent $\beta$-carbolines as potential multitarget antiAlzheimer agents, J. Med. Chem. 53 (2010) 3611-3617.

[41] O. Soukup, D. Jun, J. Zdarova-Karasova, J. Patocka, K. Musilek, J. Korabecny, J. Krusek, M. Kaniakova, V. Sepsova, J. Mandikova, F. Trejtnar, M. Pohanka, L. Drtinova, M. Pavlik, G. Tobin, K. Kuca, A resurrection of 7-MEOTA: a comparison with tacrine, Curr. Alzheimer Res. 10 (2013) 893-906. 
[42] E. Simoni, S. Daniele, G. Bottegoni, D. Pizzirani, M.L. Trincavelli, L. Goldoni, G. Tarozzo, A. Reggiani, C. Martini, D. Piomelli, C. Melchiorre, M. Rosini, A. Cavalli, Combining galantamine and memantine in multitargeted, new chemical entities potentially useful in Alzheimer's disease. J. Med. Chem. 55 (2012) 9708-9721.

[43] A.M. Reggiani, E. Simoni, R. Caporaso, J. Meunier, E. Keller, T. Maurice, A. Minarini, M. Rosini, A. Cavalli, In vivo characterization of ARN14140, a memantine/galantamine-based multi-target compound for Alzheimer's disease. Sci. Rep. 6 (2016) 33172.

[44] Z. Gazova, O. Soukup, V. Sepsova, K. Siposova, L. Drtinova, P. Jost, K. Spilovska, J. Korabecny, E. Nepovimova, D. Fedunova, M. Horak, M. Kaniakova, Z.-J. Wang, A.K. Hamouda, K. Kuca, Multi-target-directed therapeutic potential of 7-methoxytacrine-adamantylamine heterodimers in the Alzheimer's disease treatment, Biochim. Biophys. Acta 1863 (2017) 607-619.

[45] K. Spilovska, J. Korabecny, J. Kral, A. Horova, K. Musilek, O. Soukup, L. Drtinova, Z. Gazova, K. Siposova, K. Kuca, 7-Methoxytacrine-adamantylamine heterodimers as cholinesterase inhibitors in Alzheimer's disease treatment Synthesis, biological evaluation and molecular modeling studies, Molecules 18 (2013) 2397-2418.

[46] M.D. Duque, P. Camps, L. Profire, S. Montaner, S. Vázquez, F.X. Sureda, J. Mallol, M. López-Querol, L. Naesens, E. De Clercq, S.R. Prathalingam, J.M. Kelly, Synthesis and pharmacological evaluation of (2-oxaadamant-1-yl)amines, Bioorg. Med. Chem. 17 (2009) 3198-3206.

[47] P. Camps, M.D. Duque, S. Vázquez, L. Naesens, E. De Clercq, F.X. Sureda, M. López-Querol, A. Camins, M. Pallàs, S.R. Prathalingam, J.M. Kelly, V. Romero, D. Ivorra, D. Cortés, Synthesis and pharmacological evaluation of several ringcontracted amantadine analogs, Bioorg. Med. Chem. 16 (2008) 9925-9936.

[48] M.D. Duque, P. Camps, E. Torres, E. Valverde, F.X. Sureda, M. López-Querol, A. Camins, S.R. Prathalingam, J.M. Kelly, S. Vázquez, New oxapolycyclic cage amines with NMDA receptor antagonist and trypanocidal activities, Bioorg. Med. Chem. 18 (2010) 46-57.

[49] E. Torres, M.D. Duque, M. López-Querol, M.C. Taylor, L. Naesens, C. Ma, L.H. Pinto, F.X. Sureda, J.M. Kelly, S. Vázquez, Synthesis of benzopolycyclic 
cage amines: NMDA receptor antagonist, trypanocidal and antiviral activities, Bioorg. Med. Chem. 20 (2012) 942-948.

[50] E. Valverde, F.X. Sureda, S. Vázquez, Novel benzopolycyclic amines with NMDA receptor antagonist activity, Bioorg. Med. Chem. 22 (2014) 2678-2683.

[51] I. Sola, E. Aso, D. Frattini, I. López-González, A. Espargaró, R. Sabaté, O. Di Pietro, F. J. Luque, M. V. Clos, I. Ferrer, D. Muñoz-Torrero, Novel levetiracetam derivatives that are effective against the Alzheimer-like phenotype in mice: synthesis, in vitro, ex vivo and in vivo efficacy studies, J. Med. Chem. 58 (2015) 6018-6032.

[52] O. Di Pietro, F.J. Pérez-Areales, J. Juárez-Jiménez, A. Espargaró, M.V. Clos, B. Pérez, R. Lavilla, R. Sabaté, F.J. Luque, D. Muñoz-Torrero, Tetrahydrobenzo $[h][1,6]$ naphthyridine-6-chlorotacrine hybrids as a new family of anti-Alzheimer agents targeting $\beta$-amyloid, tau, and cholinesterase pathologies, Eur. J. Med. Chem. 84 (2014) 107-117.

[53] E. Viayna, I. Sola, M. Bartolini, A. De Simone, C. Tapia-Rojas, F. G. Serrano, R. Sabaté, J. Juárez-Jiménez, B. Pérez, F. J. Luque, V. Andrisano, M. V. Clos, N. C. Inestrosa, D. Muñoz-Torrero, Synthesis and multi-target biological profiling of a novel family of rhein derivatives as disease-modifying antiAlzheimer agents, J. Med. Chem. 57 (2014) 2549-2567.

[54] F.J. Pérez-Areales, O. Di Pietro, A. Espargaró, A. Vallverdú-Queralt, C. Galdeano, I.M. Ragusa, E. Viayna, C. Guillou, M.V. Clos, B. Pérez, R. Sabaté, R.M. Lamuela-Raventós, F.J. Luque, D. Muñoz-Torrero, Shogaol-huprine hybrids: Dual antioxidant and anticholinesterase agents with $\beta$-amyloid and tau anti-aggregating properties, Bioorg. Med. Chem. 22 (2014) 5298-5307.

[55] V.E. Gregor, M.R. Emmerling, C. Lee, C. J. Moore. The synthesis and in vitro acetylcholinesterase and butyrylcholinesterase inhibitory activity of tacrine (Cognex ${ }^{\circledR}$ ) derivatives, Bioorg. Med. Chem. Lett. 2 (1992) 861-864.

[56] C.G. Parsons, G. Quack, I. Bresink, L. Baran, E. Przegalinski, W. Kostowski, P. Krzascik, S. Hartmann, W. Danysz, Comparison of the potency, kinetics and voltage-dependency of a series of uncompetitive NMDA receptor antagonists in vitro with anticonvulsive and motor impairment activity in vivo, Neuropharmacology 34 (1995) 1239-1258.

[57] M.-K. Hu, C.-F. Lu, A facile synthesis of bis-tacrine isosteres, Tetrahedron Lett. 41 (2000) 1815-1818. 
[58] P. Camps, X. Formosa, C. Galdeano, T. Gómez, D. Muñoz-Torrero, M. Scarpellini, E. Viayna, A. Badia, M.V. Clos, A. Camins, M. Pallàs, M. Bartolini, F. Mancini, V. Andrisano, J. Estelrich, M. Lizondo, A. Bidon-Chanal, F.J. Luque, Novel donepezil-based inhibitors of acetyl- and butyrylcholinesterase and acetylcholinesterase-induced $\beta$-amyloid aggregation, J. Med. Chem. 51 (2008) 3588-3598.

[59] M. Barniol-Xicota, A. Escandell, E. Valverde, E. Julián, E. Torrents, S. Vázquez, Antibacterial activity of novel benzopolycyclic amines, Bioorg. Med. Chem. 23 (2015) 290-296.

[60] R.M. Lane, S.G. Potkin, A. Enz, Targeting acetylcholinesterase and butyrylcholinesterase in dementia, Int. J. Neuropsychopharmacol. 9 (2006) 101124.

[61] G.L. Ellman, K.D. Courtney, V. Andres, R.M. Featherstone, A new and rapid colorimetric determination of acetylcholinesterase activity, Biochem. Pharmacol. 7 (1961) 88-95.

[62] K. Takahashi-Ito, M. Makino, K. Okado, T. Tomita, Memantine inhibits $\beta$ amyloid aggregation and disassembles preformed $\beta$-amyloid aggregates, Biochem. Biophys. Res. Commun. 493 (2017) 158-163.

[63] C. Galdeano, E. Viayna, I. Sola, X. Formosa, P. Camps, A. Badia, M.V. Clos, J. Relat, M. Ratia, M. Bartolini, F. Mancini, V. Andrisano, M. Salmona, C. Minguillón, G.C. González-Muñoz, M.I. Rodríguez-Franco, A. Bidon-Chanal, F.J. Luque, D. Muñoz-Torrero, Huprine-tacrine heterodimers as antiamyloidogenic compounds of potential interest against Alzheimer's and prion diseases, J. Med. Chem. 55 (2012) 661-669.

[64] F.J. Pérez-Areales, N. Betari, A. Viayna, C. Pont, A. Espargaró, M. Bartolini, A. De Simone, J.F. Rinaldi Alvarenga, B. Pérez, R. Sabate, R.M. LamuelaRaventós, V. Andrisano, F.J. Luque, D. Muñoz-Torrero, Design, synthesis and multitarget biological profiling of second-generation anti-Alzheimer rheinhuprine hybrids, Fut. Med. Chem. 9 (2017) 965-981.

[65] S. Pouplana, A. Espargaro, C. Galdeano, E. Viayna, I. Sola, S. Ventura, D. Muñoz-Torrero, R. Sabate, Thioflavin-S staining of bacterial inclusion bodies for the fast, simple, and inexpensive screening of amyloid aggregation inhibitors, Curr. Med. Chem. 21 (2014) 1152-1159. 
[66] A. Espargaró, A. Medina, O. Di Pietro, D. Muñoz-Torrero, R. Sabate, Ultra rapid in vivo screening for anti-Alzheimer anti-amyloid drugs, Sci. Rep. 6 (2016) 23349.

[67] A. Espargaró, C. Pont, P. Gamez, D. Muñoz-Torrero, R. Sabate, Amyloid paninhibitors: One family of compounds to cope with all conformational diseases, ACS Chem. Neurosci. 10 (2019), 1311-1317.

[68] C.A. Lipinski, F. Lombardo, B.W. Dominy, P.J. Feeney, Experimental and computational approaches to estimate solubility and permeability in drug discovery and development settings, Adv. Drug Delivery Rev. 23 (1997) 3-25.

[69] R. Morphy, Z. Rankovic, Designing multiple ligands - medicinal chemistry strategies and challenges, Curr. Pharm. Des. 15 (2009) 587-600.

[70] L. Di, E.H. Kerns, K. Fan, O.J. McConnell, G.T. Carter, High throughput artificial membrane permeability assay for blood-brain barrier. Eur. J. Med.Chem. 38 (2003) 223-232.

[71] A. Tarozzi, M. Bartolini, L. Piazzi, L. Valgimigli, R. Amorati, C. Bolondi, A. Djemil, F. Mancini, V. Andrisano, A. Rampa, From the dual function lead AP2238 to AP2469, a multi-target-directed ligand for the treatment of Alzheimer's disease, Pharmacol. Res. Perspect. 2 (2014) e00023. 